University of Louisville

ThinkIR: The University of Louisville's Institutional Repository

Electronic Theses and Dissertations

$5-2003$

\title{
The bilingual motets of the old corpus of the Montpellier Codex.
}

Kimberly Adelle Harris

University of Louisville

Follow this and additional works at: https://ir.library.louisville.edu/etd

Part of the Music Commons

\section{Recommended Citation}

Harris, Kimberly Adelle, "The bilingual motets of the old corpus of the Montpellier Codex." (2003). Electronic Theses and Dissertations. Paper 2882.

https://doi.org/10.18297/etd/2882

This Master's Thesis is brought to you for free and open access by ThinkIR: The University of Louisville's Institutional Repository. It has been accepted for inclusion in Electronic Theses and Dissertations by an authorized administrator of ThinkIR: The University of Louisville's Institutional Repository. This title appears here courtesy of the author, who has retained all other copyrights. For more information, please contact thinkir@louisville.edu. 


\title{
THE BILINGUAL MOTETS OF THE OLD CORPUS OF THE MONTPELLIER CODEX
}

\author{
By \\ Kimberly Adelle Harris \\ B.A., Truman State University, 2001

\begin{abstract}
A Thesis Submitted to the Faculty of the Graduate School of the University of Louisville in Partial Fulfillment of the Requirements for the Degree of
\end{abstract} \\ Master of Music in Music History \\ Department of Music History \\ School of Music \\ University of Louisville \\ Louisville, Kentucky
}

May 2003 
THE BILINGUAL MOTETS OF THE OLD CORPUS OF THE MONTPELLIER CODEX

\section{By}

Kimberly Adelle Harris

B.A., Truman State University, 2001

A Thesis Approved on

April 18, 2003

By the following Thesis Committee: 


\section{ACKNOWLEDGMENTS}

My deepest appreciation goes to Dr. Julia Shinnick for her extraordinary guidance on this project. This thesis could not have come to fruition without her knowledge, suggestions, proofreading, advice, and inspiration. I also need to thank Dr. Rebecca Baltzer. Her help, via Dr. Shinnick, was invaluable to this study. Since a large number of Dr. Shinnick's resources are in Texas, I would like to thank Dr. Shinnick's husband, Tom Shinnick, for his assistance.

I must also thank my committee, Dr. Jean Christensen and Dr. Anne Marie de Zeeuw for their support and guidance on this project. I would also like to thank Dr. Jack Ashworth for his inspired introduction to early music with Early Music Ensemble.

Thanks also need to be given to my friends. To Vino Mazzei, for encouraging me to undertake a thesis in medieval music when I did not think I knew enough about medieval music to do it. To Tim Lindsley, the brave man who went through this ordeal the year before, for all his advice. To Andrey Astaiza for his help in counting intervals and taping examples. And to all my friends who gave me support and understood why I was a hermit all spring semester.

Lastly, I thank my family for supporting me from Missouri (financially and emotionally) during this stressful time; without them I would not have had the faith in myself to go to graduate school. Thanks especially to my brother, Michael, for noticing the alternating pattern in the tenor rhythms while playing them on his bassoon, and my mother, Pat, for her help in looking up Bible verses. 


\begin{abstract}
The bilingual motets of the old corpus of the Montpellier Codex (Montpellier, Faculté de Médecine, H 196) are collected in the third fascicle of this thirteenth-century codex. These eleven motets provide a sample group for the study of interrelationships among the contents of a manuscript. Elements of the music, text, and tenor sources work together to unify each individual motet as well as the eleven motets in the fascicle:

While the motets of Mo have been studied in detail, this small collection has been neglected, perhaps because of its simultaneous presentation of sacred and erotic love. It is this trait, however, that makes this fascicle a striking example of the medieval penchant for interrelationships in seemingly unrelated material. Singing simultaneous praises to the Virgin in Latin and to Marion in French seems unusual today, but in the medieval period this juxtaposition of sacred and erotic love was acceptable.
\end{abstract}




\section{TABLE OF CONTENTS}

PAGE

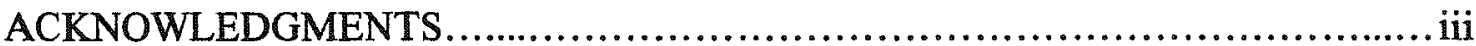

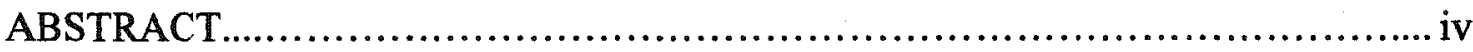

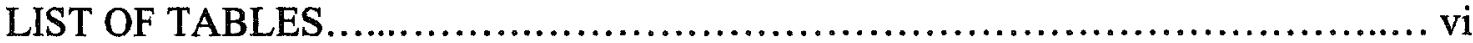

LIST OF EXAMPLES ........................................................... vii

LIST OF MANUSCRIPTS AND THEIR SIGLA $\ldots \ldots \ldots \ldots \ldots \ldots \ldots \ldots \ldots \ldots \ldots \ldots$ viii

CHAPTER

1. INTRODUCTION .........................................................

2. TENORS AND THEIR SOURCES ..................................11

3. MUSICAL CHARACTERISTICS......................................26

4. TEXTUAL CHARACTERISTICS..................................... 40

5. CONCLUSIONS: THE UNITY OF FASCICLE III.........................54

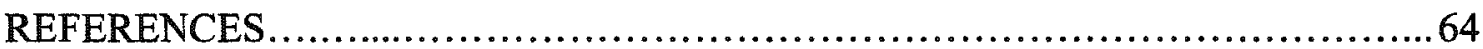

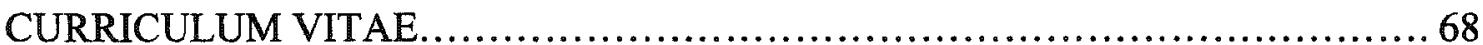




\section{LIST OF TABLES}

PAGE

CHAPTER 1

Table 1.1. Fascicles and Their Contents in Mo ....................................4

\section{CHAPTER 2}

Table 2.1. List of Motets in Mo, Fascicle III.......................................... 11

Table 2.2. Chant Sources of the Motets in Fascicle III................................ 21

Table 2.3. Rhythmic Modes of the Motets in Fascicle III..............................23

\section{CHAPTER 3}

Table 3.1. Range of Voices........................................................ 26

Table 3.2. Melodic Modes of Each Voice............................................28

Table 3.3. Rhythmic Modes of Upper Voices (based on text declamation)............. 31

Table 3.4. Percentage of Melodic Intervals............................................ 32

Table 3.5. Percentage of Melodic Intervals in No. 44 ................................32

Table 3.6. Percentage of Harmonic Intervals (on Beginnings of Perfections)............33

Table 3.7. Percentage of Harmonic Intervals (on Beginnings of Perfections) in No. $44 \ldots$

Table 3.8. Percentage of Intervals found at Cadences................................ 37

\section{CHAPTER 4}

Table 4.1. Genres of Triplum Texts................................................. 41

Table 4.2. Triplum Text Summaries............................................... 45

Table 4.3. References to Flowers in Motetus Texts of Fascicle III.....................48

Table 4.4. Intercessory Pleas found in Fascicle III.................................. 49 


\section{LIST OF EXAMPLES}

PAGE

\section{CHAPTER 2}

Example 2.1. No. 36, mm. 1-4, tenor part............................................ 12

Example 2.2. No. 37, mm. 1-3, tenor part.......................................... 13

Example 2.3. No. 38, mm. 4-11, tenor part....................................... 14

Example 2.4. No. 40, mm. 1-6, tenor part........................................... 15

Example 2.5. No. 45, entire tenor part......................................... 19

Example 2.6. The Rhythmic Modes (shortest possible ordos)......................22

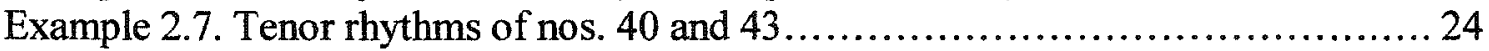

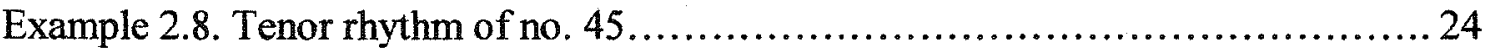

\section{CHAPTER 3}

Example 3.1. No. 36, mm. 9-13, motetus part..................................... 29

Example 3.2. No. 43 , mm. 1-5, triplum and motetus parts......................... 30

Example 3.3. No. 41, mm. 20-25, triplum and motetus parts........................ 30

Example 3.4. No. 36 , mm. 1-4, triplum part....................................... 30

Example 3.5. No. 43, mm. 21-26, tenor part ........................................... 34

Example 3.6. No. $36, \mathrm{~mm} .53-56$, triplum and motetus parts......................... 35

Example 3.7. No. 36, m. 70, triplum part......................................... 36

Example 3.8. No. $36, \mathrm{~mm}$. 61-65, triplum and motetus parts......................... 36

Example 3.9. No. 42 , mm. 29-32, motetus part................................... 37

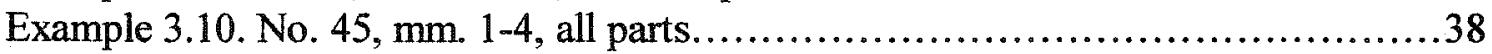




\section{LIST OF MANUSCRIPTS AND THEIR SIGLA}

ArsA Paris, Bibliothèque de l'Arsenal, 135

ArsC Paris, Bibliothèque de l'Arsenal, 8521

$\mathrm{Ba} \quad$ Bamberg, Staatsbibliothek, Lit. 115 (olim Ed.IV, 6)

Bes Besançon, Biblioteca Municipale, Ms I,716

Boul Boulogne-sur-Mer, Biblioteca Municipale, 148 (olim 119)

$\mathrm{Cl}$

Paris, Bibliothèque nationale de France, nouv. acq. F. fr. 13521 (La

Clayette)

F

Firenze, Biblioteca Laurenziana, Plut. 29,1

$\mathrm{Hu} \quad$ Burgos, Monasterio de Las Huelgas

LoB London, British Library, Egerton 274

LoC London, British Library, Add. 30091

Lyell Oxford, Bodleian Library, Lyell 72

Ma $\quad$ Madrid, Biblioteca Nationale, Ms 20486 (olim Hh 167)

Mo Montpellier, Faculté de Médecine, H 196

MuB München, Bayerische Staatsbibliothek, lat. 16443, Musik-Fragmente E III 230-231 (olim 84-85)

MuC München, Bayerische Staatsbibliothek, lat. 5539

N Paris, Bibliothèque nationale de France, fr. 12615 (Chansonnier de

Noailles)

PsAr Paris, Bibliothèque nationale de France, lat. 11266

StS Stary Sacz, Konv Swaty Kingy, D.2

StV Paris, Bibliothèque nationale de France, lat. 15139 (olim Saint Victor 813)

$\mathrm{Tu} \quad$ Torino, Biblioteca Reale, Mss vari 42

V Roma, Biblioteca Vaticana, Reg. 1490

W1 Wolfenbüttel, Herzog August Bibliothek, 628 (olim Helmst. 677)

W2 Wolfenbüttel, Herzog August Bibliothek, 1099 (olim Helmst. 1206) 


\section{CHAPTER 1: INTRODUCTION}

The motet, originating in the early thirteenth century, is one of the principal forms of polyphonic music in the medieval period. The genre originated in the clausulae of the Notre Dame school's Magnus Liber Organi through the process of adding words (different from those in the tenor) to the dupla of two-voice clausulae. Originally, the added words were Latin, like the tenor, and glossed the chant they were built upon. By the end of the thirteenth century the practice had evolved to include Latin texts not related to the tenor and French courtly love texts far removed from the ecclesiastical origin of the genre.

Composers also enjoyed adding additional lines above the tenor and duplum, now called the motetus because it contained its own text. ${ }^{1}$ These additional lines, called the triplum and the quadruplum, also carried their own independent texts. Usually, but not always, they were in the same language as the motetus. The interplay of these different texts, simultaneously presented, is the defining feature of the motet genre. The multiple texts were not randomly thrown together; medieval poet-composers carefully composed and/or selected texts that had an association with the existing motetus text, whether or not that association was readily apparent. This reflected the medieval fascination with word games and riddles.

\footnotetext{
${ }^{1}$ The word motetus comes from the French word mot, which means "word." It is from this term that we get the name for the genre.
} 
According to Christopher Page's article, "The Performance of Ars Antiqua Motets," pieces in this genre were probably composed for and by the learned class, primarily monks, scholars and other literate citizens, such as lawyers and physicians, who would have enjoyed the task of identifying multiple texts at the same time. ${ }^{2}$ Page bases his assertion on the sophistication of the motet genre; it was a challenge for the audience and performers to identify the liturgical source of the tenor and to find links between the upper lines. In French texts, refrains from troubadour and trouvère songs were frequently quoted; this was probably another source of amusement for the audience.

Three hundred and twenty-four motets are preserved in the Montpellier Codex (Montpellier, Faculté de Médecine, H 196), making it the largest source of motets of the thirteenth century. This diminutive codex, hereafter referred to by its siglum, Mo, consists of eight fascicles and measures $192 \times 136 \mathrm{~mm}^{3}$ ("not much larger than a postcard," according to Catherine Parsoneault). ${ }^{4}$ The first six fascicles make up the "old corpus," which is generally accepted as dating from the 1270 s, according to Ernest Sanders, ${ }^{6}$ or the $1280 \mathrm{~s}$, in Gilbert Reaney's opinion. ${ }^{7}$ The seventh fascicle (along with additions to the third and fifth fascicles) was added at the end of the thirteenth century. In the early fourteenth century, the eighth fascicle and the appendix to the seventh

\footnotetext{
${ }^{2}$ Christopher Page, "The Performance of Ars Antiqua Motets," Early Music 16, no. 2 (May 1988): $147-8$

${ }^{3}$ Gilbert Reaney, ed. Mamuscripts of Polyphonic Music: $11^{\text {th }}$-Early $14^{\text {th }}$ Century, Vol. B IV, part 1, Repertoire International de Sources Musicales (Munich-Duisburg: G. Henle, 1964), 272.

${ }^{4}$ Catherine Jean Parsoneault, "The Montpellier Codex: Royal Influence and Musical Taste in Late Thirteenth-Century Paris" (Ph.D diss., The University of Texas at Austin, 2001), 1.

${ }^{5}$ Sources differ on the description of the old corpus. According to Emest $\mathrm{H}$. Sanders and Peter M. Lefferts, "Sources, MS," in The New Grove Dictionary of Music and Musicians, ed. Stanley Sadie and John Tyrrell (New York: Grove Dictionaries, 2001), 23: 876, the old corpus consists of Fascicles II-VI. Reaney considers the old corpus Fascicles I-VI. Sanders and Lefferts believe that the first fascicle was added at the end of the thirteenth century at the same time as Fascicle VII.

${ }^{6}$ Sanders and Lefferts, 876.

${ }^{7}$ Reaney, 272.
} 
fascicle were added. ${ }^{8}$ Reaney advances the possibility that the eighth fascicle was once an independent manuscript, added to the codex at a later date. ${ }^{9}$ Within this codex we find over three hundred examples of thirteenth- and early fourteenth-century polyphony including 319 distinct two-, three-, and four-voice motets. ${ }^{10}$

Fascicle I contains an assortment of polyphonic works including a conductus, two hocket-motets, one hocket, and six three-part organa. Hans Tischler, in his edition of Mo, believes that these works were composed circa $1200 .^{11}$ The rest of the fascicles are dedicated to specific genres of motets. Fascicle II is comprised of triple motets (sixteen French and one Latin). ${ }^{12}$ There are eleven bilingual double motets in Fascicle III (each with a Latin motetus and a French triplum). Twenty-two Latin double motets are preserved in Fascicle IV. Fascicle V presents one hundred French double motets, and Fascicle VI contains seventy-five French (single) motets. Fascicles VII and VIII preserve thirty-nine and forty-two double motets, respectively; these are a mixture of French and Latin motets as seen in Table 1.1. ${ }^{13}$

\footnotetext{
${ }^{8}$ Sanders and Lefferts, 876.

${ }^{9}$ Reaney, 272.

${ }^{10}$ Five of the motets in Mo are duplications, so there is a total of 324 motets, but there are only 319 different ones.

${ }^{11}$ Hans Tischler, ed., The Montpellier Codex, vol. I, Critical Commentary and Fascicles 1 and 2 (Madison: A-R Editions, 1985), xxix.

${ }^{12}$ The classification of motets is based upon how many differently texted voices exist above the tenor. A single motet has one, a double motet, two, and a triple motet, three voices above the tenor. Confusion sometimes arises from the fact that a triple motet has a total of four voices. The language in the classification of a motet refers to that of the upper voice(s). A French motet has French texts in the motetus and any other upper voices, but probably has a Latin tenor incipit (although there are motets built upon French tenors).

${ }^{13}$ Sanders and Lefferts, 876.
} 
Table 1.1. Fascicles and their contents in Mo

\begin{tabular}{|l|l|l|l|l|}
\hline & Fasc. I & Fasc. II & Fasc. III & Fasc. IV \\
\hline Folios & $1-22 \mathrm{v}$ & 22v-62v & 62v-86v & $87-110 \mathrm{v}$ \\
\hline Contents & $\begin{array}{l}\text { 1 conductus setting, } \\
\text { 2 hocket-motets, 1 } \\
\text { hocket, 6 three-part } \\
\text { organa }\end{array}$ & $\begin{array}{l}\text { 16 French } \\
\text { and 1 Latin } \\
\text { triple motets }\end{array}$ & $\begin{array}{l}\text { 11 bilingual } \\
\text { motets }\end{array}$ & $\begin{array}{l}\text { 22 Latin } \\
\text { double } \\
\text { motets }\end{array}$ \\
\hline Additions & None & None & $\begin{array}{l}\text { 2 French (single) } \\
\text { motets, 2 Latin } \\
\text { (single) motets }\end{array}$ & None \\
\hline
\end{tabular}

\begin{tabular}{|l|l|l|l|l|}
\hline & Fasc. V & Fasc. VI & Fasc. VII & Fasc. VIII \\
\hline Folios & $111-230 \mathrm{v}$ & $231-269 \mathrm{v}$ & $270-349 \mathrm{v}$ & $350-397 \mathrm{v}$ \\
\hline Contents & $\begin{array}{l}\text { 100 French double } \\
\text { motets, 1 } \\
\text { Provençal double, } \\
\text { 1 French- } \\
\begin{array}{l}\text { Provençal, 1 } \\
\text { bilingual }\end{array}\end{array}$ & $\begin{array}{l}\text { 75 French } \\
\text { single } \\
\text { motets }\end{array}$ & $\begin{array}{l}\text { 39 double } \\
\text { motets (26 } \\
\text { French, 7 Latin, } \\
6 \text { bilingual) }\end{array}$ & $\begin{array}{l}\text { 42 double } \\
\text { motets (21 } \\
\text { French, 16 } \\
\text { Latin, 5 } \\
\text { bilingual) }\end{array}$ \\
\hline Additions & 1 bilingual & None & $\begin{array}{l}\text { 8 French } \\
\text { double, 1 Latin } \\
\text { double, 1 Latin } \\
\text { single, 1 } \\
\text { bilingual }\end{array}$ & None \\
\hline
\end{tabular}

Currently, there are two sets of transcriptions of Mo available. The seminal study on Mo, Polyphonies du XIIIe siècle by Yvonne Rokseth, includes a facsimile of the manuscript, two volumes of transcriptions, and a volume of critical commentary completed between 1935 and 1939. ${ }^{14}$ More recently, Hans Tischler has produced his own set of transcriptions, titled The Montpellier Codex. ${ }^{15}$ Published in 1978, his study includes commentary, transcriptions, and English translations of the French and Latin

\footnotetext{
${ }^{14}$ Yvonne Rokseth, ed., Polyphonies du XIlle siècle; le manuscript H 196 de la Faculté de médecine de Montpellier (Paris: Editions de l'Oiseau lyre, 1935).

${ }^{15}$ Hans Tischler, ed., The Montpellier Codex (Madison: A-R Editions, 1985).
} 
texts. ${ }^{16}$ In his introduction Tischler praises Rokseth's work, but comments that since (at the time of his study) four decades of research had passed, a new set of transcriptions was due.

Two studies particularly important for the musical aspects of Mo are those of Luther Dittmer and Finn Mathiassen. Dittmer contributed a groundbreaking study in 1955 titled "The Ligatures of the Montpellier Manuscript." account the three different datings proposed for the different fascicles and additions. $\mathrm{He}$ also treats both the notation cum littera (for the motetus, triplum, and quadruplum) and sine littera (for the tenor). ${ }^{18}$ Mathiassen studied the old corpus of Mo. His study, published in 1966 as The Style of the Early Motet (c. 1200-1250) ${ }^{19}$ focuses on the music and counterpoint of the motets, following an introductory discussion of the contemporaneous theoretical treatises of the time and a general analysis of the upper voices.

A number of doctoral dissertations and post-graduate studies also treat Mo. Generally, these fall into two catergories: studies on the codicology of the manuscript, and studies on the text-music relationships. The authors of the two codicological studies express opposing viewpoints. Mary Wolinski, in her dissertation "The Montpellier Codex: Its Compilation, Notation, and Implications for the Chronology of the Thirteenth-

\footnotetext{
${ }^{16}$ The translations from the Old French are by Susan Stakel; those from the Latin are by Joel Relihan.

${ }^{17}$ Luther Dittmer, "The Ligatures of the Montpellier Manuscript," Musica Disciplina 9 (1955): $35-55$

${ }^{18}$ The term cum littera refers to music written with text, which was generally written with simplices (or single notes); notation sine littera refers to untexted music which used more ligatures.

${ }^{19}$ Finn Mathiassen, The Style of the Early Motet: An Investigation of the Old Corpus of the Montpellier Manuscript (Copenhagen: Dan Fog Musikforlag, 1966).
} 
Century Motet, ${ }^{, 20}$ attempts to disprove the long-held belief that Mo was copied in three separate stages. She claims that a team of scribes and artists working together copied the entire codex at the same time. In contrast, Catherine Parsoneault, in "The Montpellier Codex: Royal Influence and Musical Taste in Late Thirteenth-Century Paris,"21 reevaluates Wolinski's work by using some new techniques. Parsoneault upholds the original belief that the codex was copied at different times.

There have been three studies conducted on the text-music relationships in the motets of Mo within the past twenty years. Beverly Jean Evans' dissertation, "The Unity of Text and Music in the Late Thirteenth-Century French Motet: A Study of Selected Works from the Montpellier Manuscript, Fascicle VII, ${ }^{, 22}$ closely examines both the texts and the music in an attempt to prove that the texts were carefully constructed to fit the music. A second doctoral study discussing motet texts centers on forty-five of the Latin works in Mo. This comprehensive study by Susan Kidwell, titled "The Integration of Music and Text in the Early Latin Motet," examines a group of motets and their source clausulae. ${ }^{23}$ Kidwell also discusses the texts separately, and then looks at the integration of text and music from many angles (tenor, melody, harmony and phrases), providing a good model for motet analysis. Robyn Smith, in her book French Double and Triple Motets in the Montpellier Manuscript ${ }^{24}$ focuses on a selection of works from Fascicles

\footnotetext{
${ }^{20}$ Mary Wolinski, "The Montpellier Codex: Its Compilation, Notation, and Implications for the Chronology of the Thirteenth-Century Motet" (Ph.D. diss., Brandeis University, 1988).

${ }^{21}$ Parsoneault, 1.

${ }^{22}$ Beverly Jean Evans, "The Unity of Text and Music in the Late Thirteenth-Century French Motet: A Study of Selected Works from the Montpellier Manuscript, fascicle VII" (Ph.D. diss., University of Pennsylvania, 1983).

${ }^{23}$ Susan Kidwell, "The Integration of Music and Text in the Early Latin Motet" (Ph.D. diss., The University of Texas at Austin, 1993).

${ }^{24}$ Robyn Smith, French Double and Triple Motets in the Montpellier Manuscript: Textual Edition, Translation and Commentary (Ottawa: Institute of Mediaeval Music, 1997).
} 
II, V, and VII. Her goal is to give a new edition and translation of the French texts.

Smith also analyzes the texts for rhyme and syllable count, and studies how these relate to the music's rhythmic perfections. ${ }^{25}$

Sylvia Huot, in her book Allegorical Play in the Old French Motet: The Sacred and the Profane in Thirteenth-Century Polyphony, ${ }^{26}$ establishes good guidelines for the analysis of motet texts. While her study is limited to the French motet genre, there are references to bilingual motets, including a few found in Fascicle III of Mo. Huot's observations and readings can be directly applied to the motets studied here.

One last study that merits mention investigates Fascicle III: "Notre Dame Bilingual Motets: A Study in the History of Music c. 1215-1245" by Gordon A. Anderson. ${ }^{27} \mathrm{He}$ takes as his subject the entire bilingual motet repertoire represented in the time period, twenty works in all. His study attempts to determine standards, or typical features, of this genre. Anderson also arranges the pieces chronologically and briefly analyzes the twenty extant bilingual motets of the thirteenth century, eleven of which are found in the third fascicle of Mo.

There are thirty-four bilingual motets found in Mo, but only eleven are found in the old corpus. ${ }^{28}$ These eleven motets, which include Latin motetti and French tripla, comprise the original third fascicle and present one component of Mo that has not been

\footnotetext{
${ }^{25}$ According to Andrew Hughes, "Franco of Cologne," in The New Grove Dictionary of Music and Musicians, ed. Stanley Sadie and John Tyrrell (New York: Grove Dictionaries, 2001), 9: 199, in medieval music, a perfection was "a unit of three breves akin to the modern bar." In modern transcriptions in $3 / 8,6 / 8$ or $9 / 8$ a perfection has the value of a dotted quarter note. Medieval theorists called for a consonance (i.e., a unison, perfect fourth, perfect fifth, or octave) on the first breve of each perfection.

${ }^{26}$ Sylvia Huot, Allegorical Play in the Old French Motet: The Sacred and the Profane in Thirteenth-Century Polyphony (Stanford: Stanford University Press, 1997).

${ }^{27}$ Gordon A. Anderson, 'Notre Dame Bilingual Motets: A Study in the History of Music c. 12151245," Miscellanea Musicologica 3 (1968): 50-145.

${ }^{28}$ The remaining twenty-three bilingual motets are found in Fascicles VII and VIII and the additions to Fascicles V and VII. The motets not part of the old corpus will not be addressed in this study.
} 
studied in depth. This fascicle, the smallest of the codex, represents a minor and shortlived subgenre in the history of the motet. These motets are based on Latin tenors from the chant repertoire; a few have clausulae sources. They present a Latin motetus and a French triplum above the tenors. The tenors use repeated rhythms as expected, and are the slowest-moving lines. Generally, the motetus moves more quickly than the tenor, and the triplum even faster than the motetus in an attempt to fit in more words, but this does not hold true for every bilingual motet.

Many of the motets from Fascicle III of Mo have identical concordances ${ }^{29}$ in other sources, principally Bamberg (Bamberg, Staatsbibliothek, Lit. 115 olim Ed.IV, 6; hereafter referred to by its siglum, $\mathrm{Ba})^{30}$ and La Clayette (Paris, Bibliothèque nationale, nouv. Acq. F. fr. 13521; hereafter referred to by its siglum, Cl). ${ }^{31}$ Several can also be found as single motets in other sources where only two voices, the tenor and either the motetus or the triplum, are present. A few also exist as triple motets with a new voice added to the two texted voices found in Mo. None of the motets in this fascicle exist without either an identical or a reduced concordance, leading us to conclude that these were popular motets and carefully selected from the current repertoire for placement in this fascicle.

${ }^{29}$ The term concordance refers to another manuscript source of motet with the same tenor. An identical concordance is a piece containing all the same voices (music and text) in another manuscript; a reduced concordance is a piece with the same tenor but lacking one or more of the upper voices.

${ }^{30}$ The Bamberg manuscript has been edited in Gordon A. Anderson, ed., Compositions of the Bamberg Mamuscript, Lit. 115 (Rome, American Institute of Musicology, 1977). See Pierre Aubry, ed., Cent motets due XIIle siècle, publiés d'après le manuscrit Ed. IV. 6 de Bamberg (New York: Broude Brothers, 1964) for a facsimile edition of Ba.

${ }^{31}$ La Clayette has been edited in Ludwig Gennrich, ed., Faksimile-ausgabe der Hs La Clayette (Darmstadt: n. p., 1958). 
Perhaps the most striking feature of the bilingual motets is their simultaneously presented French and Latin texts. The French texts deal almost exclusively with courtly love, some referring to Robin and Marion, the conventional shepherd and shepherdess characters of the Middle Ages. There is only one exception, the final motet in the fascicle, no. $46,{ }^{32}$ whose triplum comments on the hypocrisy rampant among the brothers and minor clergy. The texts of the Latin motetti are all ecclesiastical, consisting mainly of Marian epithets, although there are three non-Marian texts among them. One of these stresses that no one, especially the brothers, should be trusted, another consists of epithets to the cross, and the third is a paraphrase of a passage from the Gospel of John. ${ }^{33}$ The most obvious reason for these motets to be grouped in the same fascicle is that they are all recorded in the old corpus as bilingual motets. Looking deeper, one finds common threads throughout the eleven pieces.

Musically, the motets recorded in Fascicle III represent the motet from its beginnings to the mid- to late-thirteenth century. One is an adapted conductus-motet; two have clausulae sources; some use triplets, most do not; some remain true to the rhythmic modes; and some are so far removed from the modal system that it is hard to tell which mode, if any, an individual line is using. Harmonically, these are typical medieval polyphonic works, using perfect intervals (fourths, fifths, and octaves) at the beginning of each perfection and at cadences. There are differences, however, in the amount of dissonance that occurs in each motet. Some motets present a freer use of dissonance than others.

\footnotetext{
${ }^{32}$ Numbering used here will be that of Ludwig, Tischler, and Rokseth.
}

${ }^{33}$ See John 14:15-31. 
This study finds and discusses the unifying features of the fascicle by addressing these questions: What are the similarities and differences in these motets? What holds them together as a unit? Why might these motets have been put in this specific order? Chapter 2 discusses the origin of each motet, its tenor and liturgical source, and the complexes $^{34}$ of which each motet is a part as well as identifying the features which unify the tenors. Chapter 3 studies the musical features of the motets. Chapter 4 addresses the texts and the characteristics of the French and Latin voices. Finally, Chapter 5 discusses the overriding features that unify the fascicle and relates the motets of Fascicle III to the other contents of the codex.

${ }^{34}$ A motet complex is a group of motets based on the same tenor. Complexes often have "subcomplexes" which include motets that share an upper voice (musically and textually) in addition to the tenor. 


\section{CHAPTER 2: TENORS AND THEIR SOURCES}

The tenors of the motets in Fascicle III, as listed by Hendrik van der Werf, come from chants for the Mass, save for one that is taken from an office chant. ${ }^{35}$ There is one motet whose tenor source has yet to be identified, no. 40 , which has an incipit labeled Domino in Mo. Table 2.1 lists the incipits and tenor source feast for each of the motets in Fascicle III.

Table 2.1. List of Motets in Mo, Fascicle III

\begin{tabular}{|c|c|c|c|c|}
\hline Motet & Triplum Incipit & Motetus Incipit & Tenor Label & Feast of Tenor \\
\hline 36 & El mois d'avril & O quam sancta & Et gaudebit & Ascension \\
\hline 37 & Mout me fu gries & In omni fratre & In seculum & Easter Sunday \\
\hline 38 & Doz rossignoles & Virgo gloriosa & Letabitur & $\begin{array}{l}5^{\text {th }} \text { Sunday of } \\
\text { Pentecost }\end{array}$ \\
\hline 39 & Povre secors & Gaude chorus & Angelus & Easter Monday \\
\hline 40 & Par un matinée & Mellis stilla & Domino & unknown \\
\hline 41 & Au doz mois de mai & Crux forma & Sustinere & $\begin{array}{l}\text { Finding of the } \\
\text { Holy Cross }\end{array}$ \\
\hline 42 & Quant florist & Non orphanum & Et gaudebit & Ascension \\
\hline 43 & Quant voi l'erbe & Salve virgo & C[umque] & $\begin{array}{l}\text { Dedication of a } \\
\text { Church (Office) }\end{array}$ \\
\hline 44 & Quant repaire & Flos de spina & Regnat & Assumption \\
\hline 45 & Quant voi revenir & Virgo virginum & Hec dies & Easter Sunday \\
\hline 46 & L'estat du monde & Beata viscera & Beata viscera & BVM \\
\hline
\end{tabular}

As seen in Table 2.1, the eleven motets in Fascicle III each present a liturgical tenor, a Latin motetus, and a triplum in Old French.

\footnotetext{
${ }^{35}$ Hendrik van der Werf, Integrated Dictionary of Organa, Clausulae, and Motets of the
} Thirteenth Century (Rochester, New York: by the author, 1989) is an index to all known thirteenth-century motets. 
Before one can study the unifying features of the tenors of the motets in Fascicle III, the tenor sources need to be identified. Important information for understanding each motet includes the feast and chant from which each tenor is taken, the text of this source chant, the rhythmic mode imposed by the composer on the chant, and any clausula source for the motet.

The first motet in Fascicle III, no. 36, El mois d'avril/O quam sancta'Et gaudebit, has the same tenor as no. 42. The two motets are, however, built on different clausulae and have different texts in the upper voices, making each a part of a different subcomplex. The shared tenor melody is taken from the Alleluia for the Mass for Ascension Sunday. The text of this Alleluia is Non vos relinquam orphanos: vado et venio ad vos, et gaudebit cor vestrum (I will not leave you as orphans, I will go and I come to you and your heart will be joyous). ${ }^{36}$ As seen in Example 2.1, the motet composer has applied a rhythm related to mode 5 to the tenor.

Example 2.1. No. $36, \mathrm{~mm} .1-4$, tenor part

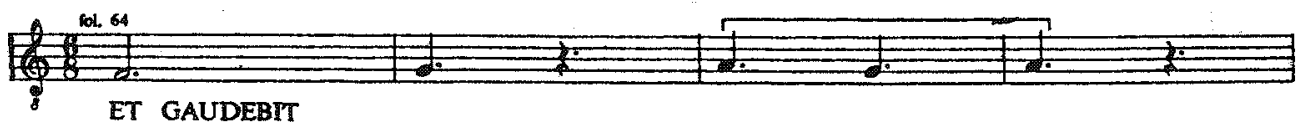

While related to mode 5 , the rhythm of this tenor is varied slightly, perhaps in an attempt to keep the line rhythmically interesting. This motet is part of a complex of nine different motets: three single Latin, two double Latin, two bilingual (one with two texts, one with three), one French single, and one French double motet. ${ }^{37}$ Based on an extant clausula

\footnotetext{
${ }^{36}$ John $14: 18$.

${ }^{37}$ O quam sancta/Et gaudebit (LoC f.3v, Hu f.94v); Memor tui/Et gaudebit (W2 f.188v); Virgo virginum/Et gaudebit (W2 f.187v); Velut stele/Ypocrite/Et gaudebit (F f.411 v); Ypocrite/O quam sancta/Et gaudebit (Ba f.47, Ma f.132); El mois d'avril/O quam sancta/Et gaudebit (Mo f.63v); El mois d'avril/O quam sancta/O Maria mater/Et gaudebit (Cl f.380v); El mois d'avril/Al cor ai/Et gaudebit (W2 f.195); Al cor ai/Et gaudebit (StV f.289v).
} 
generally accepted as composed by Perotin and found in the Florence manuscript, ${ }^{38}$ no. 36 is true to its clausula source, presenting only about a dozen slight rhythmic changes, embellishments, and differing pitches in the motetus line.

Motet no. 37, Mout me fu gries/In omni fratre tuo/In seculum, is based on an extremely popular tenor from the Gradual for the Mass for Easter Day (this chant also serves as the tenor source for No. 45 in this fascicle). The text of the respond of this gradual is a Psalm verse, Hec dies quam fecit Dominus exsultemus et laetemur in ea (This is the day the Lord has made; let us rejoice and be glad in it). ${ }^{39}$ The text of the verse is Confitemini Domino, quoniam bonus quoniam in seculum misericordia ejus (Confess to the Lord since he is righteous and without end, He will have mercy upon them). The motet composer has imposed a second mode rhythm on the pitches and used the cursus ${ }^{40}$ a total of five times. The second mode rhythm is seen in Example 2.2.

Example 2.2. No. 37, mm. 1-3, tenor part

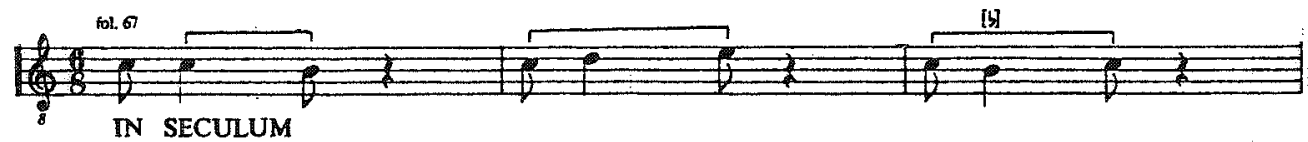

Each time the cursus is repeated, the same ordering of pitches is used, but the rhythm is varied. These different rhythms occur in an ABBAC pattern in the five repetitions of the cursus. This motet is not part of a large complex, nor does it have a clausula source; however, it does exist as a single Latin motet. The bilingual version is found in two other manuscripts, $\mathrm{Cl}$ and $\mathrm{Ba}$; the single Latin version is found in five manuscripts. ${ }^{41}$

\footnotetext{
${ }^{38}$ Rebecca Baltzer, "The Polyphonic Progeny of an Et gaudebit: Assessing Family Relations in the Thirteenth-Century Motet," in Hearing the Motet: Essays on the Motet of the Middle Ages and Renaissance, ed. Dolores Pesce (New York: Oxford University Press, 1997), 20.

${ }^{39}$ Ps. 118:24.

${ }^{40} \mathrm{~A}$ cursus is an set of pitches taken, in order, from a source chant and used in the tenor voice.

${ }^{41}$ In omni fratre/In seculum (LoB f.54v, LoC f.4v, Boul f.92, Hu f.96, Bes \#13b); Mout me fu gries/In omni fratre/In seculum (Mo f.66v, $\mathrm{Cl}$ f.376, Ba f.27).
} 
The third motet in the fascicle, no. 38, Doz rossignoles jolis/Virgo

gloriosa/Letabitur, is based on the verse of the Alleluia from the Mass for the Fifth Sunday of Pentecost. The text of the Alleluia is Alleluia: Domine, in virtute tua laetabitur rex et super salutare tuum exsultabit vehementer (Alleluia: The Lord is a virtuous and glad king and grants salvation upon those who exalt him vigorously). The tenor rhythm is the same as that used in no. 36 (Example 2.3).

Example 2.3. No. 38, mm. 4-11, tenor part

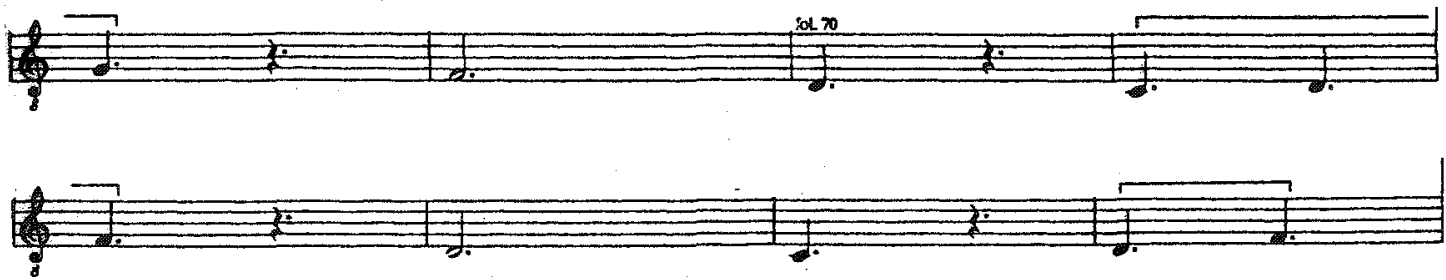

It is related to mode 5 but uses extensio, an augmentation of the rhythmic values in the mode. The cursus is used twice. In the second cursus the pitches are repeated, but the rhythm is changed in a few places. This motet has identical concordances in two other manuscripts, and both upper parts are also found as single motets with this tenor. The motetus is also found with an additional Latin text, forming a double Latin motet. ${ }^{42}$

Another motet with a tenor taken from an Alleluia verse, no. 39, Povre secors/Gaude chorus/Angelus is based on the Alleluia verse from the Mass for Easter Monday. The text of this verse is a passage from the Gospel of Matthew: Angelus Domini descendit de caelo et accedens revolvit lapidem et sedebet super eum (An Angel of the Lord came down from the sky in light, rolled back the stone, and sat upon it). ${ }^{43}$

${ }^{42}$ Douz rossignoles/Letabitur (V f.115); Virgo gloriosa/Letabitur (ArsA f.316v); Douz rossignoles/Virgo gloriosa/Letabitur (Mo f.68v, $\mathrm{Cl}$ f.375v, Tu f.32); Virgo Maria mater/Virgo gloriosa/Letabitur (Ba f.58v).

${ }^{43}$ Matt. 28:2. 
Unlike nos. 36 through 38 which only use the pitches from a word or two from their chant source, this motet takes the pitches from eight words as the melody source for its tenor: Angelus Domini descendit de caelo et accedens revolvit. The composer has used a mode 2 rhythm on the tenor pitches of this motet (as in Example 2.2). The cursus is repeated two times in its entirety, and after these two statements, an extra six perfections (which are not related to the cursus or the chant source) are added to finish the piece. This motet is part of a rather large motet complex. An identical concordance to this piece is found in Ba. It also exists as a French double motet in Fascicle V of Mo with two different French texts (and a different triplum melody). In all, this tenor provides the foundation for two single Latin motets, ${ }^{44}$ one single French motet, two double French motets, and the present bilingual motet, a total of six motets. ${ }^{45}$ From the number of extant motets on this tenor, it can be assumed that this tenor was rather popular.

Motet no. 40, Par un matinée/Mellis stilla/Domino is the one motet in the fascicle for which the tenor source has not been identified. In van der Werf's directory it is listed with the "Motets with Latin Tenors of Unknown Origin" under the tenor designation, "Domino II." As seen in Example 2.4, the rhythmic mode of this tenor is not clear (two repetitions of the rhythmic pattern are shown).

Example 2.4. No. 40, mm. 1-6, tenor part
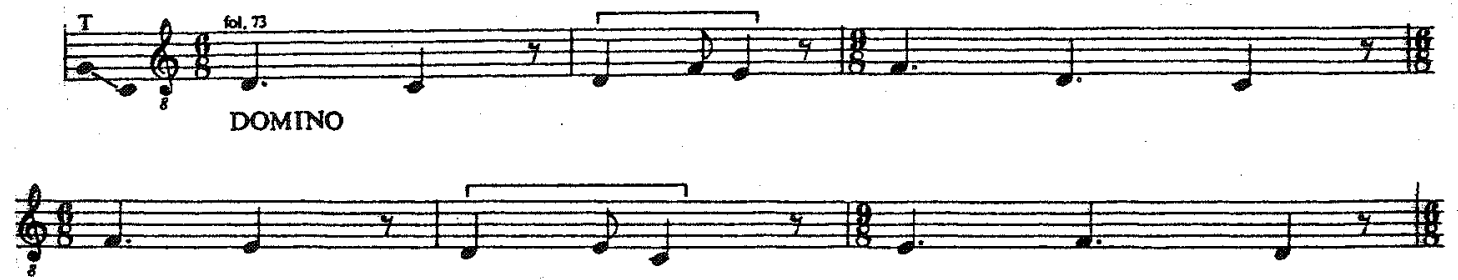

${ }^{44}$ One is incomplete, found only in theoretical treatises as a fragment.

${ }^{45}$ Gaude chorus devota/Angelus (inc. only in treatises); Gaude chorus omnium/Angelus (Ma f.134, Hu f.87); Aucuns m'ont par/Angelus (W2 f.252v, N f.181v); Aucuns m'ont par/J'ai si bien/Angelus (Mo 
This rhythm does not follow any single established rhythmic modes, but instead combines elements of modes 1 and 5 . The cursus consists of four repetitions of this rhythmic pattern, and there are two presentations of the cursus in the motet. This motet is part of a modest-sized complex,${ }^{46}$ comprised of four motets with differing texts built on this tenor. The original motet appears to have been a popular single Latin motet with the Mellis stilla text for the motetus line. It is preserved in at least eight manuscripts. The bilingual version found in $\mathrm{Mo}$ is also found in $\mathrm{Cl}$. In addition to the bilingual version, there are two double Latin versions and a double French motet found in $\mathrm{Mo}^{47}$ on this tenor, but the motetus lines of these pieces do not carry the same music. It is interesting to note that this motet contains the tenor farthest removed from the system of rhythmic modes, and it is the only motet whose tenor source remains a mystery.

Motet no. 41, Au doz mois de mai/Crux forma penitentie/Sustinere is found at the mid-point of the fascicle, the sixth of the eleven motets. ${ }^{48}$ This motet borrows its tenor from the Alleluia for the Mass for the Feast of the Finding of the Holy Cross, celebrated on May 3. The text of the verse of this Alleluia is a series of epithets to the Cross: Dulce lignum, dulces clavos, dulcia ferens pondera quae sola fuisti digna sustinere regem caelorum et Dominum (Sweet wood, sweet nails, sweet iron which alone was worthy to sustain the King and Lord of heaven). The tenor of no. 41 uses rhythmic mode 5 and includes three statements of the cursus; the third varies the rhythm slightly. The complex

f.174v); Aucuns m'ont par/Povre secors/Angelus (Cl f.390); Povre secors/Gaude chorus omnium/Angelus (Mo f.71v, Ba f.19v).

${ }_{46}$ Mellis stilla/Domino (ArsA f.290v, Gautier D-1 f.3, Ca f.129v, ArsC f.180, MuC f.73, Lyell f.173, Boul f.1v, Bes \#2); Par une matinee/Mellis stilla/Domino (Mo f.72v, Cl f.374v); O Maria mater pia/Mellis stilla/Domino (PsAr f.40v); Virginis preconia/Mellis stilla/Domino (Ba f.36).

${ }^{47}$ Mo f.209v (Fascicle V).

${ }^{48}$ The significance of this placement will be discussed in Chapter 4 . 
of occurrences for no. 41 consists of the bilingual version, two double Latin motets, and a single Latin motet. ${ }^{49}$

The next motet, no. 42, Quant florist la violete/Non orphanum/Et gaudebit, uses the same tenor as no. 36 . The clausula source for no. 42 , like that of no. 36 , is found in the Florence manuscript. This motet, like no. 36 , is extraordinarily true to its clausula source with only a few minor changes to the clausula's duplum. Motet no. 42 is also found in the manuscript $\mathrm{Ba}$ and preserved as a single Latin motet with only the Non orphanum text in no less than five manuscripts. There is also a double French version of this motet preserved in $\mathrm{Mo},{ }^{50}$ making a total of three different motets in the complex. ${ }^{51}$

The ninth motet in the fascicle, no. 43, Quant voi l'erbe/Salve virgo/Cumque, is the only motet in the fascicle with a tenor based on an office chant. The Cumque melody is from a Responsory verse for the third nocturn of Matins for the Feast of the Dedication of a Church. The text is Terribilis est locus iste non est hic aliud nisi domus Dei et porta coeli. Vere etenim Dominus est in loco isto, et ego nesciebam. Cumque evigilasset Jacob de somno ait (Awesome is this place, in no other place but this is God's home and the gate to heaven. Truth is here because the Lord is in this place, and I am ignorant. He says always be watchful of Jacob sleeping). Like no. 39 , motet no. 43 contains the pitches from more than a few words of its source, borrowing the melody from the entire Responsory verse. The tenor rhythm in this motet is ambiguous and closely related to

${ }^{49}$ Cruci domini sit/Sustinere (LoC f.7); Cruci domini sit/Crux forma/Sustinere (Ba f.11); Arbor nobilis/Crux forma/Sustinere (MuB f.V); Au douz mai/Crux forma/Sustinere (Mo f.74v, Cl f.375, Bes \#13a).

${ }^{50}$ Mo f.183v (Fascicle V).

${ }^{51}$ Non orphanum/Et gaudebit (F f.405, W2 f.174v, Hu f.92, StS \#21, Bes \#20); Quant florist/Non orphanum/Et gaudebit (Mo f.75v, Ba f.42v); Quant florist/El mois de mai/Et gaudebit (Mo f.183v). 
that of no. 40. There is only one cursus of the tenor. There is a small complex of two bilingual motets and one French double motet built upon this tenor. ${ }^{52}$

The tenor of the ninth motet, no. 44, Quant repaire la verdor/Flos de spina/Regnat, is one of two Marian tenors found in this fascicle. The text of this chant, Hodie Maria virgo caelos ascendit gaudete quia cum Christo regnat in aeternum (Today the Virgin Mary ascends rejoicing because Christ reigns eternally), is from the Alleluia verse for the Feast of the Assumption. The motet composer has set the tenor to a mode 5 rhythm, and there are two complete statements of the cursus. Two successive clausulae from W1 serve as sources for the tenor and motetus lines. ${ }^{53}$ This motet is not found in any other manuscript as a double motet, and the only other version of this motet is a single Latin motet. ${ }^{54}$ It is interesting that only two Marian tenors are present in this fascicle, since so many of the motetus texts contain epithets to the Virgin Mary.

The shortest motet of the fascicle is no. 45 , Quant voi revenir/Virgo virginum/Hec dies. With twenty-eight perfections, no. 45 is exactly one hundred perfections shorter than the previous motet. The tenor of this motet is from the same chant as that of no. 37 . As seen in Example 2.5, the rhythmic mode used for this tenor is best described as mode 1 with the use of rests.

${ }^{52}$ Douce dame par amour/Salve virgo/Cumque (Ba f.53, Da f.lvb); Douce dame par amour/Quant voi l'erbe/Cumque (Mo f.191v); Quant voil l'erbe/Salve virgo/Cumque (Mo f.77v).

${ }^{53}$ W1 f. 59 (51) \#2 and $\# 3$; \#2 serves as source for the first cursus of the motetus, $\# 3$ for the second cursus of the motetus.

${ }^{54}$ Flos de spina/Regnat (W2 f.147 and f.180). 
Example 2.5. No. 45, entire tenor part

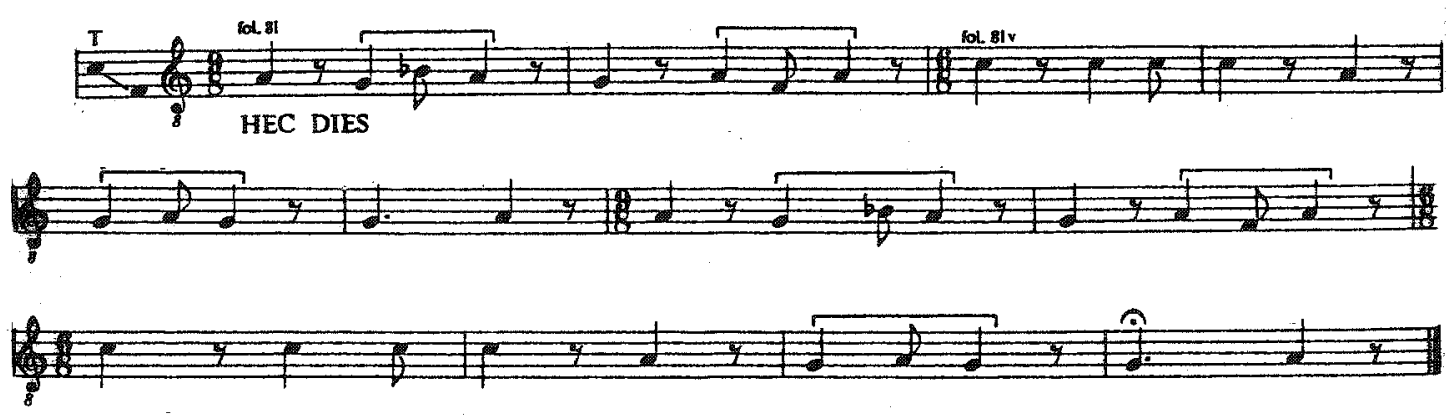

This tenor rhythm is related to the tenor rhythm of no. 40 , but uses quarter notes and eighth-note rests where no. 40 uses dotted quarter notes. Even though this motet is quite short, there are two complete statements of the cursus. The Hec dies tenor serves as the basis for twelve motets, only one of which, however, is related to the present bilingual motet. The tenor and motetus are found as a double Latin motet in Ba with a different triplum text. ${ }^{55}$ This motet is also preserved in $\mathrm{Cl}$ as a bilingual motet. ${ }^{56}$

Motet no. 46, L'estat du monde/Beata viscera/Beata viscera, the last bilingual motet in the fascicle, is the second motet with a Marian tenor. This tenor is taken from the communion antiphon for the Mass of the feasts of the Blessed Virgin Mary. The entire text, Beata viscera Maria Virginis quae portaverunt aeterni Patris Filium (Blessed womb of the Virgin Mary which carried the eternal Father's Son), serves as the source for the tenor melody. The mode 5 tenor cursus is used only once. No. 46 is part of a small complex, consisting of three motets: a single Latin motet and double Latin motet, in addition to the bilingual version. ${ }^{57}$

\footnotetext{
${ }^{55}$ O mitissima virgo/Virgo virginum/Hec dies (Ba f.60).

${ }^{56} \mathrm{Cl} \mathrm{f} .388 \mathrm{v}$.

${ }^{57}$ L'estat du monde/Beata viscera/Beata viscera (Mo f.81v); Beata viscera/Beata viscera (ArsA f. 316, ArsC f.177); Partus fuit/Beata viscera/Beata viscera (Ba f.7v).
} 
Like the other ten motets in the fascicle, no. 46 presents a tenor taken from the liturgy of the church. This characteristic is the basic unifying factor of the tenors of Fascicle III, which creates a religious foundation for the motets. The tenor rhythms are integrated in their use of the rhythmic modes. These two elements provide the groundwork for the coherence of this fascicle. The tenors of Fascicle III work to unify the group of motets in multiple ways.

As mentioned previously, all of the motets take their tenors from Mass or Office chants; no motets in this fascicle use secular French tenors. Broadly speaking, the chant sources for these tenors relate either to Christ or to the Virgin Mary. The tenors relating to Christ mainly come from feasts of the Temporale that occur after the Crucifixion, including Easter, Ascension, Finding of the Holy Cross, and Pentecost. Two tenors take their sources from Marian feasts, one from the Assumption Alleluia and one from the Communion antiphon, a chant common to all feasts of the Virgin. Only two chants do not fit into this broad classification scheme: the tenor from the Office for the Dedication of the Church, no. 43, and the yet-to-be-identified Domino, no. 40 .

The tenor from the Feast for the Dedication of the Church, no. 43, is different in many ways: 1) this tenor is the only chant taken from an office, 2) it is part of a feast that is celebrated at a different time in every church (depending on the church's day of dedication), 3) its use of rhythmic mode is ambiguous, and 4) its source text is unusual in the context of the tenors used in the other motets. Two characteristics of the C[umque] tenor, however, support the logic of its use in the fascicle: 1) the date of the Feast of the Dedication of the Church associated with this tenor is 24 February, ${ }^{58}$ placing it on the

58 The C[umque] chant is extant in three manuscripts, only one which is of French provenance, the St. Denis Antiphoner (Paris, Bibliothèque nationale de France, lat. 17296). This source, which dates from 
early end of the dates spanned by the feasts represented in this fascicle, and 2) the

distinctive tenor rhythm is closely related to that of no. 40 . With some nudging, no. 43

fits into the season of the other tenors of the fascicle, starting on 24 February with the

Dedication of St. Denis and ending with the Assumption on 15 August, creating a

springtime and summertime foundation for the upper voices.

All the tenors found in Fascicle III are from responsorial or antiphonal chants, and they favor the use of words and music from Alleluias. As seen in Table 2.2, of the eleven motets, only four use other types of chants. ${ }^{59}$

Table 2.2. Chant Sources of the Motets in Fascicle III

\begin{tabular}{|l|l|l|}
\hline Motet No. & Chant source & Feast \\
\hline $\mathbf{3 6}$ & Alleluia & Ascension \\
\hline $\mathbf{3 7}$ & Gradual & Easter Sunday \\
\hline $\mathbf{3 8}$ & Alleluia & $5^{\text {th }}$ Sunday of Pentecost \\
\hline $\mathbf{3 9}$ & Alleluia & Easter Monday \\
\hline $\mathbf{4 0}$ & Unknown & Unknown \\
\hline $\mathbf{4 1}$ & Alleluia & Finding of the Holy Cross \\
\hline $\mathbf{4 2}$ & Alleluia & Sunday after Ascension \\
\hline $\mathbf{4 3}$ & Office Responsory & Dedication of a Church \\
\hline $\mathbf{4 4}$ & Alleluia & Assumption \\
\hline $\mathbf{4 5}$ & Gradual & Easter Sunday \\
\hline $\mathbf{4 6}$ & Communion antiphon & Feasts of the BVM \\
\hline
\end{tabular}

The office chant text used is a Responsory from the third nocturn of Matins. The text and music of this tenor are actually borrowed from the verse. The final motet, no. 46 , is drawn from a communion antiphon used on feasts of the Virgin Mary. The remaining two motets not based on Alleluias borrow text and music from the same Gradual. No. 37 uses

the mid-twelfth century, was copied for the Royal Abbey of Saint-Denis, the most important cathedral in France prior to the rise of the cathedral of Notre-Dame-de-Paris. Because this is the only extant source of the C[umque] chant from France and because of St. Denis' importance as a cathedral during the time these motets were composed, the date for the Office of the Dedication of a Church at St. Denis, 24 February, will be used for this study.

${ }^{59}$ This does not include the unknown Domino tenor. 
the pitches from one word of the verse and no. 42 presents the pitches from the incipit of this Gradual for the Mass for Easter Sunday. The presentation of Alleluia verses seems to be a trait common to the motet genre in general. A glance at van der Werf's list of motets shows that a large number of motets and motet complexes are built on tenors borrowed from Alleluias.

The tenor rhythms, perhaps more than their textual features, unify the motets in this fascicle. The rhythms presented in the tenors show the break from the strict modal rhythms that occurred during the thirteenth century. Example 2.6 presents the six rhythmic modes.

Example 2.6. The Rhythmic Modes (shortest possible ordos)
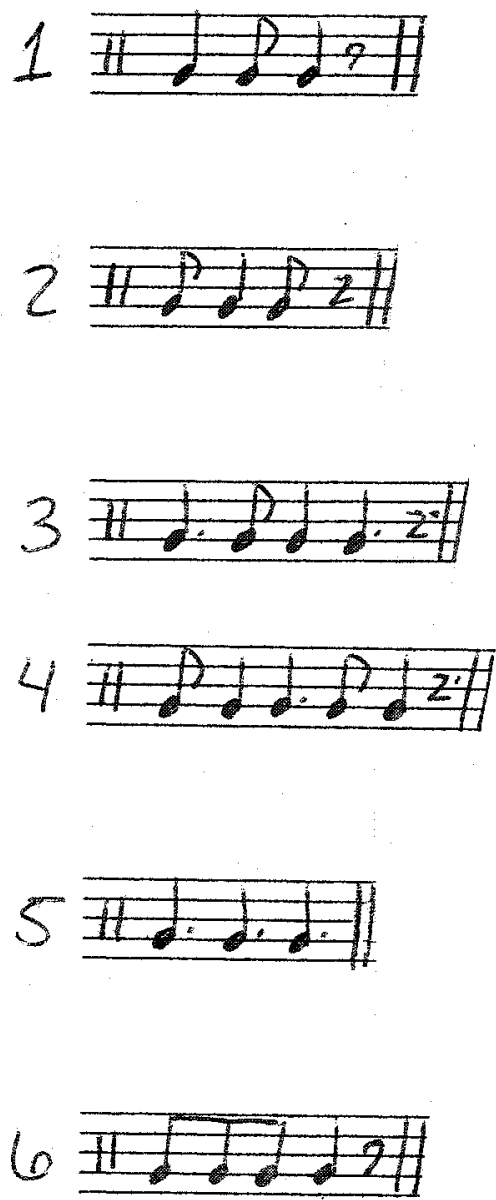
One can see that the rhythm of the tenors of Fascicle III do not always correlate with the rhythmic modes, but they do, however, originate in this tradition. Six of the eleven motets have rhythms based on mode 5 : nos. $36,38,41,42,44$, and 46 . In this group two tenors, nos. 41 and 46 , adhere fairly strictly to mode 5 , while the remaining four use an extensio version. As can be seen in Table 2.3, these motets based on mode 5 seem to occur in an alternating pattern with non-mode 5 tenors, with the exception of no. 41 , whose special placement in the fascicle will be discussed in depth later in Chapter 4 .

Table 2.3. Rhythmic Modes of the Motets in Fascicle III

\begin{tabular}{|l|l|}
\hline Motet No. & Tenor Rhythmic Mode \\
\hline $\mathbf{3 6}$ & Derivative of Mode 5 \\
\hline $\mathbf{3 7}$ & Mode 2 \\
\hline $\mathbf{3 8}$ & Derivative of Mode 5 \\
\hline $\mathbf{3 9}$ & Mode 2 \\
\hline $\mathbf{4 0}$ & Derivative of Mode 1 \\
\hline $\mathbf{4 1}$ & Mode 5 \\
\hline $\mathbf{4 2}$ & Derivative of Mode 5 \\
\hline $\mathbf{4 3}$ & Derivative of Mode 2 \\
\hline $\mathbf{4 4}$ & Derivative of Mode 5 \\
\hline $\mathbf{4 5}$ & Derivative of Mode 1 \\
\hline $\mathbf{4 6}$ & Mode 5 \\
\hline
\end{tabular}

Interspersed with the mode 5 tenors are five motets with more rhythmically-involved tenors loosely based on modes 1 and 2. Nos. 37 and 39 use a tenor rhythm based on mode 2 (Example 2.2, above). The tenors of these two motets remain true to this modal pattern for the majority of each piece. As seen in Example 2.7, nos. 40 and 43 are inversely related in their tenor patterns. 
Example 2.7. Tenor rhythms of nos. 40 and 43

No. 40

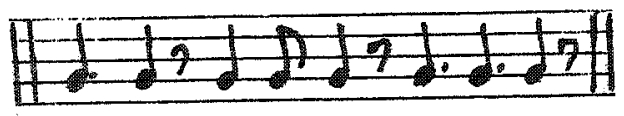

No. 43

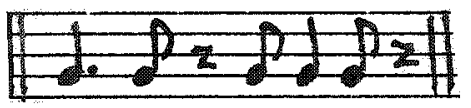

After an opening dotted quarter, eighth note, and quarter rest, the tenors of motets 40 and 43 use patterns of modes 1 and 2, respectively. No. 43 has another three perfections of dotted quarter, dotted quarter, quarter, and eighth rest before starting the rhythmic pattern over again. These patterns defy modal rhythm classifications. The rhythmic pattern of no. 45 is unique in the fascicle, and can be seen in Example 2.8.

Example 2.8. Tenor rhythm of no. 45

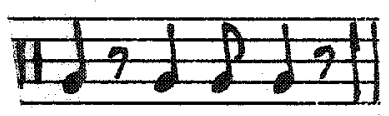

This rhythm is based in mode 1 , and like that of no. 45 uses rests in place of eighth notes. $^{60}$

The two groups of tenors, those based on mode 5 and those based on modes 1 and 2 , are carefully placed within the fascicle. The slower, mode 5 tenors alternate with the non-mode 5 tenors with the exception of no. 41 . This motet, however, is carefully placed in the fascicle because of its motetus line Crux forma (Cross, form) forming the crux, or middle, of the fascicle. The compiler continued the pattern after no. 42 , following it to

${ }^{60}$ This is also evident in the rhythms of the upper voices, but these will be discussed in Chapter 4 . 
the end of the original fascicle. In other words, if nos. 40 and 41 were switched, the pattern of mode 5 tenor, non-mode 5 tenor, would be perfect. This pattern might have been planned purposely by the compiler to draw attention to what he wanted to be the central, "crux" motet.

An understanding of the tenors of Fascicle III provides the foundation for a study of the motets built upon them. Typical of motets in the thirteenth century, the tenors illustrate the religious origin of the motet and the break from that origin by their use of a small portion of an original plainchant. Fascicle III also shows the movement away from the tradition of modal rhythms that occurred in the thirteenth century. The poetcomposer's use of more creative rhythms exemplifies the progressive trend of motets of the time. These tenors are unified by two factors. First, with the large repertoire of plainchant sources, the similarity of the times of the feasts used in these ten identified tenors cannot be coincidental. Secondly, the organization of the tenor rhythms in the alternation of mode 5 with other modes also adds to the coherence of this fascicle. 


\section{CHAPTER 3: MUSICAL CHARACTERISTICS}

The musical characteristics of the motets of Fascicle III are not unique; rather, they are typical of thirteenth-century motets as whole. In the search for unity among the musical characteristics it is useful to analyze the ranges, melodic modes, rhythmic modes of the upper voices, melodic intervals, harmonic intervals, and cadences of these eleven motets.

In the original manuscript, movable $\mathrm{C}$ clefs are used to notate pitches, with limited use of ledger lines. Both Tischler and Rokseth present their transcriptions in octave $\mathrm{G}$ clef. ${ }^{61}$ The total range of all parts of the motets of Fascicle III extends from $\mathrm{c}$ to $\mathrm{c}^{2}$, as seen in Table 3.1. ${ }^{62}$

Table 3.1. Range of Voices and Finals

\begin{tabular}{|c|c|c|c|c|c|c|}
\hline $\begin{array}{l}\text { Motet } \\
\text { No. }\end{array}$ & $\begin{array}{l}\text { Tenor } \\
\text { Range }\end{array}$ & $\begin{array}{l}\text { Motetus } \\
\text { Range }\end{array}$ & $\begin{array}{l}\text { Triplum } \\
\text { Range }\end{array}$ & $\begin{array}{l}\text { Total } \\
\text { Range }\end{array}$ & Interval & $\begin{array}{l}\text { Finals } \\
(\mathrm{T}, \mathrm{M}, \mathrm{Tr})\end{array}$ \\
\hline 36 & c to b-flat & f to $g^{1}$ & $g$ to $a^{1}$ & $c$ to $a^{1}$ & $\mathrm{P} 8+\mathrm{M} 6$ & $a^{\prime}, a^{\prime}, e^{1}$ \\
\hline 37 & f to $e^{T}$ & $\mathrm{~g}$ to $\mathrm{c}^{2}$ & $\mathrm{c}^{1}$ to $\mathrm{c}^{2}$ & $f$ to $c^{2}$ & $\mathrm{P} 8+\mathrm{P} 5$ & $f, c^{1}, f^{1}$ \\
\hline 38 & $c$ to $c^{T}$ & f to $g^{1}$ & $f$ to $a^{1}$ & $c$ to $a^{1}$ & $\mathrm{P} 8+\mathrm{M} 6$ & $\mathrm{~g}, \mathrm{~d}^{\prime}, \mathrm{g}^{\mathrm{I}}$ \\
\hline 39 & $c$ to $c^{T}$ & $c$ to $\mathrm{e}^{1}$ & $f$ to $f^{\prime}$ & $c$ to $f^{2}$ & $\mathrm{P8}+\mathrm{P} 4$ & $\mathrm{c}, \mathrm{g}, \mathrm{c}^{1}$ \\
\hline 40 & c to $\mathrm{g}$ & $\mathrm{g}$ to $\mathrm{g}^{\mathrm{I}}$ & f to $g^{I}$ & $\mathrm{c}$ to $\mathrm{g}^{1}$ & $\mathrm{P} 8+\mathrm{P} 5$ & $\mathrm{~d}, \mathrm{~d}^{1}, \mathrm{a}$ \\
\hline 41 & f to $d^{1}$ & e to $\mathrm{g}^{\mathrm{T}}$ & $\mathrm{g}$ to $\mathrm{a}^{\mathrm{I}}$ & $\mathrm{e}$ to $\mathrm{a}^{\mathrm{T}}$ & $\mathrm{P} 8+\mathrm{P} 4$ & $g, g, d^{I}$ \\
\hline 42 & c to b-flat & f to $a^{1}$ & f to $a^{l}$ & $c$ to $^{1}$ & $\mathrm{P} 8+\mathrm{M} 6$ & $a, e^{1}, e^{1}$ \\
\hline 43 & $c$ to $d^{1}$ & $c$ to $d^{I}$ & $g$ to $f^{\prime}$ & $c$ to $f^{1}$ & $\mathrm{P} 8+\mathrm{P} 4$ & $\mathrm{~d}, \mathrm{a}, \mathrm{d}^{\mathrm{I}}$ \\
\hline 44 & $c$ to $c^{1}$ & $c$ to $d^{1}$ & f to $g^{1}$ & $\mathrm{c}$ to $\mathrm{g}^{1}$ & $\mathrm{P} 8+\mathrm{P} 5$ & $\mathrm{~g}, \mathrm{~g}, \mathrm{~g}$ \\
\hline 45 & f to $c^{\prime}$ & $c^{1}$ to $c^{2}$ & $c^{1}$ to $c^{2}$ & $f$ to $c^{2}$ & $\mathrm{P} 8+\mathrm{P} 5$ & $a, a^{1}, e^{1}$ \\
\hline 46 & $\mathrm{c}$ to $\mathrm{c}^{\mathrm{T}}$ & $c$ to $\mathrm{e}^{\mathrm{I}}$ & $\mathrm{c}$ to $\mathrm{e}^{\mathrm{T}}$ & $c$ to $e^{I}$ & $\mathrm{P} 8+\mathrm{M} 3$ & $\mathrm{~d}, \mathrm{a}^{\mathrm{T}}, \mathrm{d}^{\mathrm{T}}$ \\
\hline
\end{tabular}

${ }^{61}$ Also known as vocal tenor clef.

${ }^{62}$ In this study, "c $\mathrm{c}$ " designates middle $c$. All pitch references are to sounding pitch. 
The largest range covered by the three voices of any one motet is an octave plus a major sixth; this is found in nos. 36,38 and 42 and in all the cases the range involved is $\mathrm{c}$ to $\mathrm{a}^{\mathrm{l}}$. The smallest range is present in no. 46: an octave plus a major third, spanning $\mathrm{c}$ to $\mathrm{e}^{1}$. Only two motets, nos. 37 and 45, use the high end of the total range of the fascicle, extending to $c^{2}$. It is interesting that these two motets are also based on the same chant, although each uses a different segment of it. All but three of the motets use the low part of the range; nos. 37,41 and 45 descend only to $f$, a fourth above the low $c$.

The three parts cross often. In general, the upper two voices frequently lie in the same tessitura while the tenor is usually somewhat lower. The tenor voice does not cross the motetus nearly as much as the motetus and triplum cross. The range and tessitura of these motets imply that three people with similar vocal ranges probably performed these pieces.

Medieval composers and theorists did not typically think of polyphonic pieces in terms of melodic mode. Individual lines, especially tenors taken from the plainchant repertoire, were modal, but a polyphonic piece as a whole was not considered a modal work. Johannes de Grocheio, in his treatise De musica of c.1300, says that "measured music," which includes motets, is not categorized by mode:

Certain people describe a tone by saying that it is a rule that judges every song by its end. But these men seem to err in many ways, for when they speak of "every song" they seem to include popular and measured song. This kind of song does not perhaps proceed through the rules of a tone, nor is it measured by them. Further, if it is measured by them, they do not speak of the method by which it is used nor do they make mention about it. ${ }^{63}$

${ }^{63}$ Albert Seay, Johannes de Grocheio: Concerning Music (Colorado Springs: Colorado Music Press, 1967), 31, quoted in Harold S. Powers and Frans Wiering, "Mode III, 1," in The New Grove Dictionary of Music and Musicians, 2d ed., ed. Stanley Sadie and John Tyrrell (New York: Grove Dictionaries, 2001): 16: 797. Grocheio considers organum, conductus, and motets examples of measured music, music that has to be precisely measured in order for the multiple lines to end together. 
According to Grocheio, measured song does not use the rules of the melodic modes, and therefore cannot be classified by them.

Grocheio's opinion notwithstanding, for the sake of discussing the melodic organization of these motets, it is helpful to distinguish a melodic mode for each line. In Table 3.2, a letter " $\mathrm{T}$ " following the mode indicates a transposition.

Table 3.2. Melodic Modes of Each Voice

\begin{tabular}{|l|l|l|l|}
\hline $\begin{array}{l}\text { Motet } \\
\text { No. }\end{array}$ & $\begin{array}{l}\text { Tenor } \\
\text { Mode }\end{array}$ & $\begin{array}{l}\text { Motetus } \\
\text { Mode }\end{array}$ & $\begin{array}{l}\text { Triplum } \\
\text { Mode }\end{array}$ \\
\hline $\mathbf{3 6}$ & $3 \mathrm{~T}$ & $4 \mathrm{~T}$ & $4 \mathrm{~T}$ \\
\hline $\mathbf{3 7}$ & 5 & 6 & 6 \\
\hline $\mathbf{3 8}$ & $\mathbf{8}$ & 7 & 7 \\
\hline $\mathbf{3 9}$ & $5 \mathrm{~T}$ & $5 \mathrm{~T}$ & $6 \mathrm{~T}$ \\
\hline $\mathbf{4 0}$ & 2 & 2 & 2 \\
\hline $\mathbf{4 1}$ & $\mathbf{8}$ & 7 & 7 \\
\hline $\mathbf{4 2}$ & $3 \mathrm{~T}$ & $4 \mathrm{~T}$ & $4 \mathrm{~T}$ \\
\hline $\mathbf{4 3}$ & 1 & 1 & 2 \\
\hline $\mathbf{4 4}$ & $\mathbf{8}$ & 8 & 7 \\
\hline $\mathbf{4 5}$ & $4 \mathrm{~T}$ & $3 \mathrm{~T}$ & $3 \mathrm{~T}$ \\
\hline $\mathbf{4 6}$ & 1 & 1 & 1 \\
\hline
\end{tabular}

The process of distinguishing the melodic modes of these motets involved two steps: first, an analysis of the tenors based on final, range, and pattern of whole and half steps, and secondly, a similar analysis of the upper voices. ${ }^{64}$ Six of the motets, nos. 36, 37, 38, 41,42 and 45 use the tenor in the authentic range of the mode and the upper voices in the plagal range. Three, nos. 39,43 and 44 , present the tenor and motetus in the authentic range and the triplum in the plagal range. Two, nos. 40 and 46, offer similar ranges for all three voices. In no. 40 the range of the tenor is only a fifth, $c$ to $g$, while the ranges of the motetus and triplum are almost identical. In no. 46, both upper voices have the same

${ }^{64}$ If an upper line does not end on the final of its mode, it closes on the fifth, creating the typical perfect fifth sonority at the end of the piece. 
range ( $c$ to $\mathrm{e}^{\mathrm{l}}$ ), the entire range of the piece, while the tenor covers one octave of the total range $\left(c\right.$ to $\left.c^{1}\right)$. The range of each line is often greater than an octave, but identifying a mode for each voice and matching it with one of the same final as the tenor, offers an efficient means of classifying these motets.

While the motets of Fascicle III present a variety of melodic modes among the upper voices, there is not nearly as much variety among the rhythmic modes of these voices. Identifying the rhythmic modes used in the upper voices is more difficult than identifying their melodic modes. ${ }^{65}$ Generally, there is much fractio ${ }^{66}$ present in the upper voices, which obscures the modal pattern. In order to facilitate the identification of the rhythmic mode of a cum littera line with fractio, one can look at the pattern of text declamation. While pitches often change without a change in the syllable, the pattern of text declamation often remains the same throughout each voice, thus the duration of the syllables presents a constant pattern. Multiple pitches on a single syllable are notated with the use of ligatures in the manuscript, primarily the plica $(7)$, podatus $($ ), torculus (1), and currentes (n) Tischler's transcriptions, ligatures are indicated by bracketing quarter notes or by barring eighth and sixteenth notes.

In Example 3.1, syllables are articulated primarily on beats 1,3,4, and 6 in a $6 / 8$ meter despite the fractio present on beat 1 of measures 10 and 12 .

Example 3.1. No. 36, mm. 9-13, motetus part

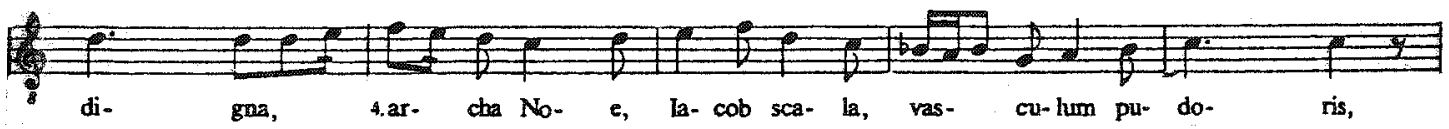

${ }^{65}$ Chapter 2 discusses the rhythmic modes of the tenors.

${ }^{66}$ Fractio is a breaking of the values of the rhythmic mode, such as subdividing a quarter note into two eighth notes, an eighth note into two sixteenth notes, etc. 
his is an example of text declamation in rhythmic mode 1 (e.g., ar-cha no-e, set to D). Conversely, the text shown in Example 3.2 changes syllables on beats 1,2 , 4 , and 5 .

Example 3.2. No. 43, mm. 1-5, triplum and motetus parts

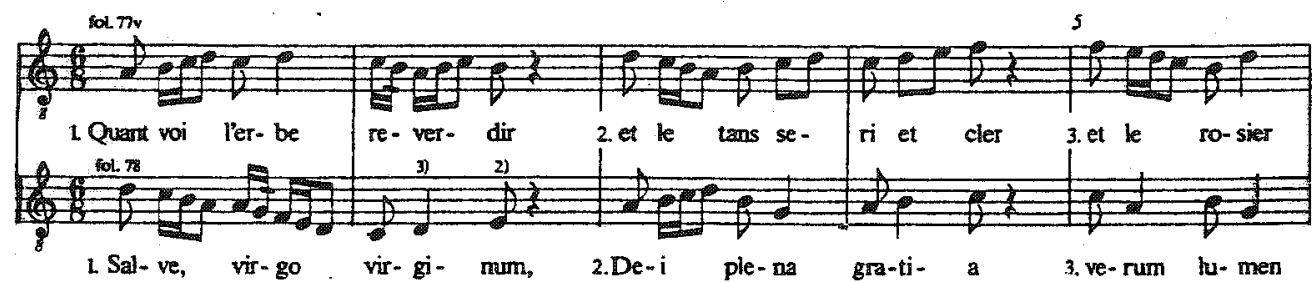

Text declamation in mode 2 is apparent in this example. Despite the rapid subdivision of the perfection, the articulation of syllables remains constant in a mode 2 pattern. In Example 3.3, syllables are articulated primarily on beats 1,4 , and 5 .

Example 3.3. No. 41, mm. 20-25, triplum and motetus parts

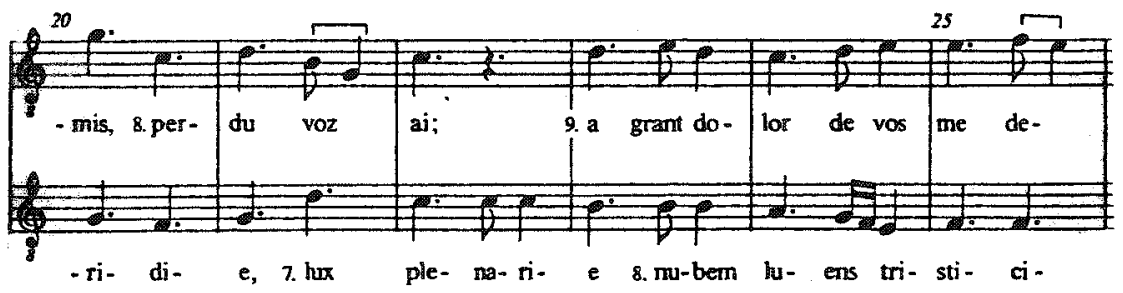

This represents text declamation in mode 3. Example 3.4 presents text declamation which changes syllable on every beat.

Example 3.4. No. 36, mm. 1-4, triplum part

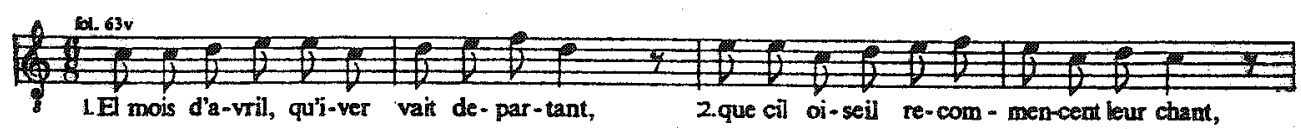

This is an illustration of text declamation in mode 6 , which is found only in quicklymoving triplum lines. 
Based on the rhythm of their text declamation, the rhythmic modes presented in the upper voices are primarily 1,2 or 6 (Table 3.3 ).

Table 3.3. Rhythmic Modes of Upper Voices (based on text declamation)

\begin{tabular}{|l|l|l|l|}
\hline $\begin{array}{l}\text { Motet } \\
\text { No. }\end{array}$ & $\begin{array}{l}\text { Motetus } \\
\text { Mode }\end{array}$ & $\begin{array}{l}\text { Triplum } \\
\text { Mode }\end{array}$ & Comment \\
\hline $\mathbf{3 6}$ & 1 & 6 & M has some extensio \\
\hline $\mathbf{3 7}$ & 2 & 6 & M has 6 in m. 24-38 \\
\hline $\mathbf{3 8}$ & 1 & 6 & \\
\hline $\mathbf{3 9}$ & 2 & 6 & Tr slows down at end for refrain \\
\hline $\mathbf{4 0}$ & 1 & 6 & \\
\hline $\mathbf{4 1}$ & 3 & 3 & Some fractio in both voices \\
\hline $\mathbf{4 2}$ & 1 & 1 & \\
\hline $\mathbf{4 3}$ & 2 & 2 & \\
\hline $\mathbf{4 4}$ & 1 & 1 & Tr has 6 in m. 41-46 and 61-62 \\
\hline $\mathbf{4 5}$ & 1 & 1 & \\
\hline $\mathbf{4 6}$ & 3 & $3 / 5$ & M unclear, uses both \\
\hline
\end{tabular}

The order of motets in the fascicle creates a pattern of sorts with regard to the rhythmic modes in the upper voices. The first half of the fascicle presents motets in which the text declamation of the triplum is moving more quickly than the motetus (mode 6 in the triplum, mode 1 or 2 in the motetus). The second half of the fascicle presents motets that state their upper voice texts at the same rate (both voices in mode 1,2 , or 3 ). The middle motet, no. 41 , and the final motet, no. 46 , are the only ones that use mode 3 . This is especially appropriate for the central, "crux" motet, since the number " 3 " was considered the perfect number and represented the Trinity, the persons of which intersected at the crucifixion.

While the rhythmic modes of Fascicle III are rather obscure, the intervals present in the fascicle are typical of thirteenth-century motets. Melodic, or linear, intervals used in Fascicle III are those expected in vocal music and comprise mainly steps and small leaps. As seen in Table 3.4, stepwise motion, by half or whole step, accounts for $77 \%$ of 
the triplum intervals, $80 \%$ of the motetus intervals, and $73 \%$ of the tenor intervals found in Fascicle III.

Table 3.4. Percentage of Melodic Intervals

\begin{tabular}{|l|l|l|l|}
\hline & $\mathbf{m} 2$ \& M2 & $\mathbf{m 3} \& \mathbf{M} 3$ & Total \\
\hline Triplum & $77 \%$ & $18 \%$ & $95 \%$ \\
\hline Motetus & $80 \%$ & $15 \%$ & $95 \%$ \\
\hline Tenor & $73 \%$ & $22 \%$ & $95 \%$ \\
\hline
\end{tabular}

Thirds, minor or major, account for $18 \%$ of triplum intervals, $15 \%$ of motetus intervals, and $22 \%$ of tenor intervals. The remaining $5 \%$ of intervals represent motion greater than a major third, including perfect fourths and fifths.

As with any averages, there are some motets that stray from the norm. As seen in Table 3.5 , in no. $44,26 \%$ of the triplum's melodic intervals are thirds, well above the average of $18 \%$. Thirty percent of the melodic intervals in the motetus line of no. 44 are thirds, twice the average of $15 \%$.

Table 3.5. Percentage of Melodic Intervals in No. 44

\begin{tabular}{|l|l|l|l|}
\hline & $\mathbf{m} 2$ \& M2 & $\mathbf{m 3} \& \mathbf{M 3}$ & Total \\
\hline Triplum & $67 \%$ & $26 \%$ & $93 \%$ \\
\hline Motetus & $65 \%$ & $30 \%$ & $95 \%$ \\
\hline Tenor & $80 \%$ & $9 \%$ & $89 \%$ \\
\hline
\end{tabular}

This triplum also contains one of only two leaps by major sixth found in all of the tripla of the fascicle.

Examining the harmonic intervals used in the motets, one finds similar results. As expected, perfect intervals -- unisons, octaves, fourths and fifths -- account for the vast majority of sonorities at the beginnings of perfections. These are the consonant intervals preferred from the advent of polyphony. Included in Table 3.6 are the 
percentages for Fascicle III as well as Finn Mathiassen's calculations for the entire old corpus. $^{67}$

Table 3.6. Percentage of Harmonic Intervals (on Beginnings of Perfections)

\begin{tabular}{|l|l|l|l|l|}
\hline & P1 \& P8 & P4 & P5 & Total \\
\hline $\begin{array}{l}\text { Tenor and both } \\
\text { upper voices }\end{array}$ & $36 \%$ & $6 \%$ & $46 \%$ & $88 \%$ \\
\hline $\begin{array}{l}\text { (Mathiassen's } \\
\text { Figures) }\end{array}$ & $(35 \%)$ & $(6 \%)$ & $(40 \%)$ & $(81 \%)$ \\
\hline $\begin{array}{l}\text { Triplum and } \\
\text { Motetus }\end{array}$ & $32 \%$ & $29 \%$ & $22 \%$ & $83 \%$ \\
\hline
\end{tabular}

Vertical sonorities produced by the tenor sounding with either upper line on a perfection usually produces a perfect interval. Thirty-six percent of these intervals are unisons or octaves, $6 \%$ are fourths, and $46 \%$ are fifths, percentages in keeping with those found by Mathiassen within the entire old corpus of Mo. Intervals present between the two upper voices, the motetus and the triplum, are slightly different: $32 \%$ are unisons or octaves, $29 \%$ are fourths, and $22 \%$ are fifths. This increase in fourths is a result of the usual arrangement of voices in the early motet: a fifth between the tenor and the motetus and a fourth between the motetus and the triplum, standard 8-5-4 voicing. There are exceptions to these averages; again, no. 44 is unusual (Table 3.7).

Table 3.7. Percentage of Harmonic Intervals (on Beginnings of Perfections) in No. 44

\begin{tabular}{|l|l|l|l|l|}
\hline & P1 \& P8 & P4 & P5 & Total \\
\hline $\begin{array}{l}\text { Tenor and both } \\
\text { upper voices }\end{array}$ & $27 \%$ & $11 \%$ & $36 \%$ & $74 \%$ \\
\hline $\begin{array}{l}\text { Motetus and } \\
\text { Triplum }\end{array}$ & $38 \%$ & $8 \%$ & $38 \%$ & $84 \%$ \\
\hline
\end{tabular}

Many of the percentages in no. 44 differ from the averages. In this motet, only $74 \%$ of the intervals between the tenor and each of the upper voices are perfect intervals, as

\footnotetext{
${ }^{67}$ Finn Mathiassen, The Style of the Early Motet (Copenhagen: Dan Fog Musikforlag, 1966), 135.
} 
opposed to the $88 \%$ in the fascicle as a whole. This is because no. 44 presents more thirds and sixths on the beginning of perfections and consequently sounds more "triadic" to our modern ears.

Intervals present at cadences in these motets also need to be studied. At final cadences, there is always a fundamental tone in the tenor, and in ten of the eleven motets a fifth is present in one of the upper voices. No. 42 , contains a doubled fifth, while in no. 44, all three voices end on the same pitch.

Movement to the final cadences in these motets is by step, either an ascending or descending minor or major second. This is true for all lines of all eleven motets in Fascicle III, with only one exception. In no. 43 the tenor descends a perfect fifth to its cadence pitch (Example 3.5).

Example 3.5. No. 43 , mm. 21-26, tenor part

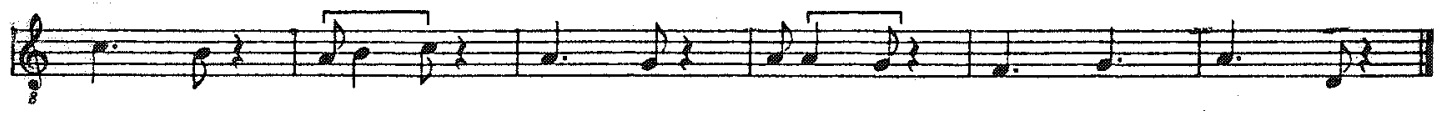

Triplum and motetus lines, newly composed to create these motets, approach their cadential pitches by step, suggesting that this was the cadential motion preferred by the composer. ${ }^{68}$ Tenors, however, were taken from the plainchant repertoire, and the poetcomposers could not change the sequence of pitches already present within the chant segments. While to our modern ears medieval cadences may sound abrupt and crude due to the presence of parallel perfect intervals, they were the norm for the medieval aesthetic. exceptions.

${ }^{68}$ The motetus lines of the three motets (nos. 36, 42, and 44) created from clausula sources are 
Internal, linear cadences in each voice also need to be identified in a survey of the musical characteristics of these motets. Typically, individual upper voices cadence frequently, at the end of most lines of text. Each line of text usually comprises a grammatical unit or phrase and is set off by punctuation in the transcription of the text. ${ }^{69}$ Most cadences are easily heard as such because each is followed by a rest. There are two basic types of cadences found in thirteenth-century motets: unflourished and flourished. ${ }^{70}$ Unflourished cadences achieve the cadence pitch at the beginning of a perfection as indicated in Example 3.6 by the letter "U."

Example 3.6. No. 36, mm. 53-56, triplum and motetus parts

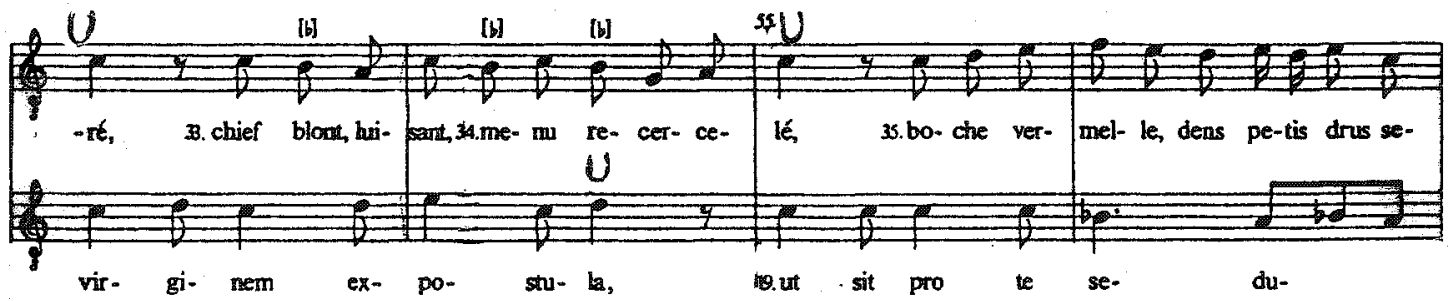

Unflourished cadences represent the majority of cadences found in Fascicle III. Out of all the cadences in the motetus and triplum lines, $87 \%$ are unflourished. Flourished cadences are cadences in which the actual cadence pitch is not achieved on a strong beat. Occasionally the final syllable occurs at the beginning of a perfection, but this is followed by stepwise melodic movement, usually down, to the cadence pitch (Example 3.7 ).

\footnotetext{
${ }^{69}$ Punctuation is not found in the manuscript. cadences.

${ }^{70}$ These terms are mine. In older studies these are often referred to as masculine and feminine
} 
Example 3.7. No. $36, \mathrm{~mm} .70$, triplum part

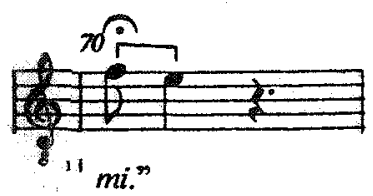

As expected, the remaining $13 \%$ of cadences in the motetti and tripla of Fascicle III are flourished cadences.

Not all cadences are easily heard as unflourished or flourished. Some unflourished cadences often look like flourished cadences due to the fact that they contain a few transitional pitches that lead into the next phrase, thus creating an elision between the two phrases. Upon closer inspection one finds that the cadence pitch is achieved on the perfection and what follows is actually a transition into the next phrase. A transitional cadence in both voices can be seen in Example 3.8, indicated by the letter "T."

Example 3.8. No. 36, mm. 61-65, triplum and motetus parts

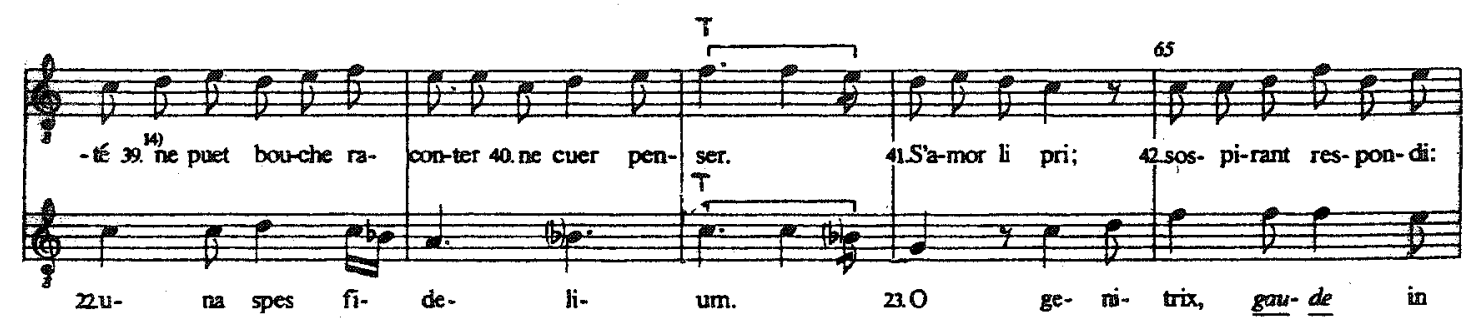

In measure 63 of both lines, the final syllable of the line is articulated on beat 1 . The music continues, however, and leads into the next phrase.

The intervals used at linear cadences are concurrent with the intervals found in the individual vocal lines (Table 3.8). 
Table 3.8. Percentage of Intervals found at Cadences

\begin{tabular}{|l|l|l|l|}
\hline & Tripla & Motetti & Total \\
\hline Minor 2 $^{\text {nd }}$ & $21.0 \%$ & $14.5 \%$ & $17.8 \%$ \\
\hline Major 2 $^{\text {nd }}$ & $42.1 \%$ & $57.3 \%$ & $49.6 \%$ \\
\hline Minor 3 $^{\text {rd }}$ & $13.1 \%$ & $13.3 \%$ & $13.2 \%$ \\
\hline Major 3 $^{\text {rd }}$ & $6.7 \%$ & $7.1 \%$ & $6.9 \%$ \\
\hline Perfect 4 $^{\text {th }}$ & $2.0 \%$ & $0.8 \%$ & $1.4 \%$ \\
\hline Perfect 5 5 $^{\text {th }}$ & $1.2 \%$ & $0.8 \%$ & $1.0 \%$ \\
\hline Major 6 $^{\text {th }}$ & $0.0 \%$ & $0.4 \%$ & $0.2 \%$ \\
\hline Same Note & $13.9 \%$ & $5.8 \%$ & $9.9 \%$ \\
\hline
\end{tabular}

Typical intervallic motion at a cadence is by whole step, more commonly ascending but often descending. Thirds, major and minor, are also found at linear cadences in most motets of Fascicle III. In all but one motet, no. 36, one leap of a perfect fourth or fifth is found at a linear cadence in either the triplum or motetus. The motetus line of no. 42 , in addition to one ascending perfect fourth, also contains one leap of a sixth at a cadence point shown in Example 3.9.

Example 3.9. No. 42, mm. 29-32, motetus part

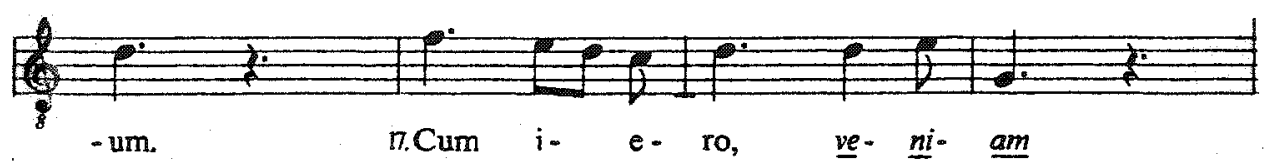

This leap at a cadence is unprecedented in the fascicle and must have been a challenge for the vocalist.

Looking for internal vertical cadences is almost futile. One voice of a motet rarely comes to a resting point simultaneously with another voice. When two voices do come to a cadence point together, it is usually the tenor voice with one of the upper voices due to the fact that the tenor cadences every measure or two depending on its rhythmic pattern. Cadences between the two upper voices do not occur often in these motets, and simultaneous cadences in all three voices of a motet are rare, with the 
exceptions of final cadences and occasional internal cadences conveying some structural importance. One such internal cadence occurs between the two repetitions of the cursus in no. 36. This is due to the asynchronic nature of the text; the lines do not have regular numbers of syllables nor do the phrases have regular numbers of perfections. Between the two texted lines of a motet there is no correlation of number of syllables per line or perfections per phrase. This is a compositional feature of the motet genre which sets it apart from the conductus and conductus-motet.

One motet in Fascicle III, no. 45, breaks these norms. This short motet, only lasting 28 perfections, contains eight cadences, in all of which the three voices line up (Example 3.10).

Example 3.10. No. 45, mm. 1-4, all parts

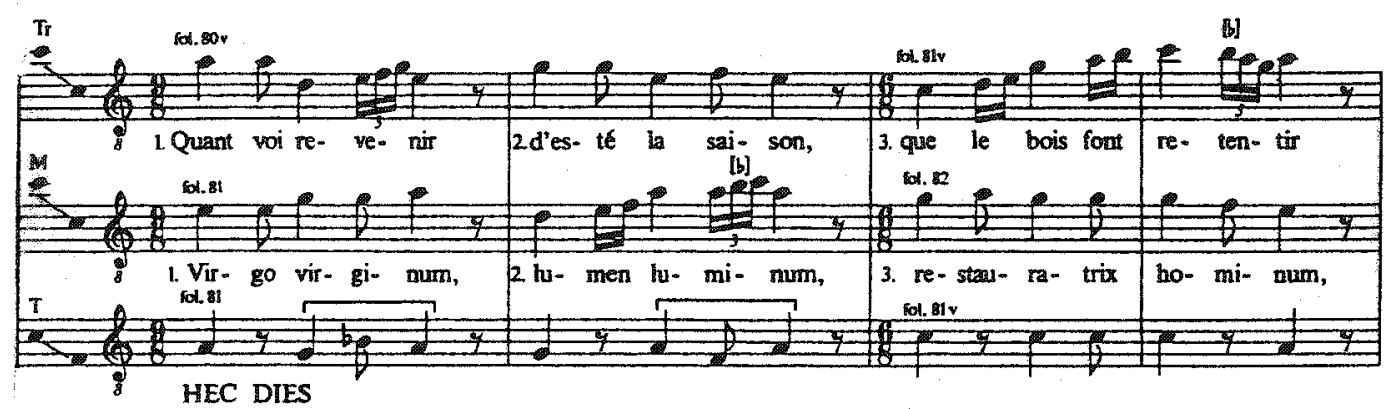

In this motet either the texts were written at the same time, or the text that was added later was carefully constructed to fit with the existing text. This motet, with its eight simultaneous cadences in all three voices, provides evidence that the poet-composer was thinking vertically while writing a new text and line.

In general, the musical characteristics of Fascicle III are not extraordinary in comparison with other thirteenth-century motets. The harmonic and linear intervals used in the melodic lines and at cadences are typical of polyphony of the late thirteenth 
century. The use of rhythmic modes is apparent in the text declamation of the upper voices, although it is obscured by the use of fractio. The use of conventional musical elements and the apparent thought that went into these pieces shows that the poetcomposer was a skilled musician, knowledgeable in the compositional practices of his time. The musical characteristics may be typical of the thirteenth century, but they nonetheless contribute to the unity of the eleven motets of Fascicle III. 


\section{CHAPTER 4: TEXTUAL CHARACTERISTICS}

The texts of the motets of Fascicle III epitomize two rich genres of medieval literature. In the motetus texts, one finds prime examples of sacred, although not liturgical, literature; simultaneously, in the triplum texts, examples of courtly love texts, closely related to those of the trouvères, occur. A close examination of these texts' general characteristics yields a number of examples of textual links within several individual motets. ${ }^{71}$ Such textual links help to unify the fascicle.

The Latin and French texts found in Fascicle III are fairly representative of similar texts throughout the codex. In discussing the French texts of the manuscript in Tischler's edition of the codex, Susan Stakel notes, "Many of the Montpellier pieces are trite and drab by any literary standards." ${ }^{.72}$ The vast majority of the French texts in the codex are in the style of the troubadour canso, and many also represent the pastourelle genre. These texts almost exclusively deal with a knight desiring the affection of a shepherdess, and his attempts to act upon his feelings. Interspersed with these pastourelle and canso texts, a few different types appear. According to Stakel, these include primarily "portrayals of the poet sitting around the fire with friends, drinking good red wine, and eating roasted capon. ${ }^{9,73}$ Equally present among the non-canso and non-pastourelle French texts are sirventes, courtly poems criticizing the loss of morality

\footnotetext{
${ }^{71}$ Links between the texts of different motets are addressed in Chapter 5.

${ }^{72}$ Susan Stakel, "The French Texts," in The Montpellier Codex, ed. Hans Tischler, vol. 4, xvi. Madison: A-R Editions, 1985.

${ }^{73}$ Ibid., xix.
} 
in the world. The one sirventes found in Fascicle III is the only text among the tripla of the bilingual motets that does not relate to the subject of love.

There are three types of courtly texts present in the tripla of the motets of Fascicle III: canso, pastourelle, and sirventes.

Table 4.1. Genres of Triplum Texts

\begin{tabular}{|l|l|}
\hline Motet & Triplum Text \\
\hline $\mathbf{3 6}$ & Pastourelle \\
\hline $\mathbf{3 7}$ & Canso \\
\hline $\mathbf{3 8}$ & Canso \\
\hline $\mathbf{3 9}$ & Canso \\
\hline $\mathbf{4 0}$ & Pastourelle \\
\hline $\mathbf{4 1}$ & Pastourelle \\
\hline $\mathbf{4 2}$ & Canso \\
\hline $\mathbf{4 3}$ & Canso \\
\hline $\mathbf{4 4}$ & Pastourelle \\
\hline $\mathbf{4 5}$ & Canso \\
\hline $\mathbf{4 6}$ & Sirventes \\
\hline
\end{tabular}

These texts were probably composed in or around Paris in the thirteenth century, the time the trouvères were flourishing in northern France. While the texts are not actual trouvère songs (the text of a motet is not nearly as long as that of trouvère song, nor do motet texts contain the regular rhyme scheme and line length found in the courtly tradition), they frequently borrow popular refrains from trouvère songs.

The texts of six tripla found in Fascicle III are representative of the canso genre. In these love poems the narrator praises the lady's beauty, but laments the fact that the object of his desire will not fulfill his wishes. One text, no. 42 , is unique because here the poet is actually happy. He has won his lady, she is beautiful, and he will always be true to her. No. 43 might also fall in this category since its text praises love, but this short text never reveals whether the poet has found the love he desired. The other French tripla in the canso style portray the poet in a state of despair because the lady he wants will not 
return his affection. Two include the fact that the lady has left him, and the other two merely mention a desire for a specific lady.

Four of the French tripla in Fascicle III are representative of the pastourelle genre of trouvère song. Typically, a pastourelle is a lyric song which features a man or knight who rides into an orchard or some other nature setting and comes across a beautiful girl collecting flowers or tending sheep. Often she is singing. Usually the man makes an effort to win the girl's affection, and she either accepts or rejects him. In some cases when he is rejected, the man will take what he wants from her anyway. Two of the four pastourelle texts in Fascicle III epitomize the genre. Nos. 36 and 44 both feature the conventional pastourelle opening of a man or knight riding into a flowering orchard in the springtime, coming across a beautiful maiden, and offering his love to her. In both texts the girl rejects him because she already has a lover from whom, she says, she will never part. Nos. 40 and 41 also employ the conventional pastourelle opening; however, their stories do not exactly follow the prototype. In both of these texts the man initially finds Marion crying because Robin is gone, but the two texts also end differently from the typical pastourelle. No. 40 tells of Marion lamenting, while the narrator, apparently, watches, but does not intervene; then Robin arrives, and he and Marion leave together. Marion also laments in no. 41 , but in this text Robin has actually left her. The narrator intervenes in this text and tries to comfort her. The text ends there; it is not clear whether or not the narrator attempts to win Marion's affection.

There is one text among the eleven tripla in Fascicle III which does not relate to love but is nonetheless a part of the courtly tradition. The triplum text of no. 46 , the last motet in the fascicle, is a typical sirventes text that laments the loss of morality among 
the Jacobins and brothers of the minor orders. Here the poet mentions that people who have an outwardly religious appearance are actually full of envy, pride, and hypocrisy. This text stands alone at the end of the courtly love texts and creates quite a "stinger." A different reading of the triplum text of no. 46 is possible if one considers that the courtly narrator, rejected by the woman in no. 44 , has directed his anger toward the clergy. If read this context, the poet in this text laments that all women are full of hypocrisy and deceit and only want a man who can elevate their social status. This would be an appropriate ending to a collection of texts in which the narrator has lost his lady.

Common images are found among the triplum texts of these motets. Most are typical of courtly love genres, but they still work to unify the texts of the fascicle as a whole. These images -- including birds, flowers, references to the time of year, and the description of the girl -- work to link the triplum texts of the pieces found in Fascicle III.

Birds are mentioned in seven of the eleven triplum texts. Among the birds mentioned in these seven tripla are the nightingale (named in nos. 36,38 , and 43), the lark (nos. 36 and 44), the thrush, starling, and calandra (all three in no. 36), and parrots (no. 42). Nos. 40 and 45 simply mention birds in general. Typically, birds are used to set up the story, creating a pastourelle scene for the poem. In one motet, no. 38 , the narrator addresses the nightingale throughout the text and pleads for the bird to listen to his tale of woe. This text is unique among the tripla in the fascicle as the only one addressed to someone or something.

\footnotetext{
74 "Stinger" is a term associated with film and other media music. The purpose of a stinger is to punctuate an emotion and sometimes to startle an audience.
} 
Flower imagery is prevalent in the triplum texts as well. Two types of flower imagery occur in the triplum texts. First, flower imagery is used when the narrator is describing the scene. Typically, the narrator refers to a wood (nos. 36, 40, 45), orchard (nos. 36, 41, 44), or meadow (no. 40) where flowers are blooming. The other type of reference to flowers occurs when the narrator describes his love. Frequently the narrator describes her as having lily-white skin and rose-red lips (nos. $36,37,38,42$ ).

The conventional description of the girl's beauty is found in many of the tripla of

Fascicle III. The most inclusive description is found in no. 38 .

Chief a blondet, com ors e[s]t reluisant, tres bien, pleisant, front bien compassé, plain et bien seant, euz vairs et rians, simples, bien assis, amorous a devis, fait por cuer d'amant embler. Nez a longuet, droit, tres bien feit, ce m'est vis; sorcis a traitis, menton a voutis, boche vermellete et douz ris, denz drus et petis, blans et compassement mis. Comme rose par desus lis est sa face et son cler vis; cors a tres bien fait et par devis, cuers amorous, gais, jolis et gentis. Dieus, sa tres grant biauté, sa grant bonté si m'a conquis.

She has blond hair which gleams like gold - so fair, so pleasing - a clear, broad, well-shaped brow, laughing gray-blue eyes-candid, nicely spaced, perfectly sensuous, made to steal the heart of a lover. Her nose in my opinion is noble and straight; finely drawn eyebrows, a rounded chin, scarlet lips, and a sweet laugh, tiny, straight, white, even teeth. Her face and clear complexion are like a rose set against lily-white; she has a perfectly shaped body and a heart which is loving, gay, joyful and genteel. God, her very great beauty and her great goodness have conquered me. ${ }^{75}$

The only characteristic left out of this description is a mention of the lady's breasts, but the triplum of no. 42 comments on mameletes a si duretes poignans et petitetes (her small, firm, pointing breasts). Similar characteristics, with surprisingly little change, are found in a number of texts as the man is describes his lover, or the lady he wants for his lover. Some motet texts are too short, however, to include a lengthy description of her beauty. The concept of a conventional beauty was just as typical in the thirteenth century as it is now in the twenty-first.

\footnotetext{
${ }^{75}$ Stakel, 14
} 
Another theme found in the triplum texts of Fascicle III is a reference to the time of year. Some texts explicitly state that it is the month of April (nos. 36 and 40) or May (no. 41). Others are less direct and allude to a season like summertime (no. 45). Three texts make no direct reference to a time of year but imply one in their opening. For instance, in nos. 42,43 , and 44 the narrator says that flowers are blooming, grass is turning green, and there are early buds, respectively. Descriptions such as these would lead the audience to believe that it is springtime. Only the texts of nos. $38,39,45$, and 46 have no direct references or allusions to a time of year.

When read in sequence, without the motetus texts, the triplum texts form a complete narrative. Generally speaking, they swing between positive and negative emotional experiences for the narrator and Marion.

Table 4.2. Triplum Text Summaries

\begin{tabular}{|c|c|c|}
\hline Motet & Group & Summary of Triplum Text \\
\hline 36 & 1 & Narrator propositions lady; she already has a lover \\
\hline 37 & 1 & $\begin{array}{l}\text { Lady left narrator; he laments and promises to always } \\
\text { be true to her }\end{array}$ \\
\hline 38 & 1 & $\begin{array}{l}\text { Narrator upset because he is in love with a lady who } \\
\text { does not return his affections }\end{array}$ \\
\hline 39 & 1 & Narrator upset because lady left him \\
\hline 40 & 2 & Marion sad, narrator tries to comfort her, Robin arrives \\
\hline 41 & 2 & Marion sad, narrator tries to comfort her \\
\hline 42 & 3 & Narrator is happy because he has his perfect love \\
\hline 43 & 3 & $\begin{array}{l}\text { Narrator is happy because he wants to serve his perfect } \\
\text { love }\end{array}$ \\
\hline 44 & 4 & Narrator propositions lady; she has a lover already \\
\hline 45 & 4 & Narrator is sad; wants Marion \\
\hline 46 & 5 & $\begin{array}{l}\text { Brothers are hypocrites, the state of the world gets } \\
\text { worse everyday }\end{array}$ \\
\hline
\end{tabular}

The texts can be grouped by the emotions they express. Nos. 36-39 comprise the first group and feature the narrator unhappy due to unrequited love. Nos. 40 and 41 , the second group, shift the focus to Marion; she is upset because Robin has been away for 
some time. In no. 40, Robin arrives and the story ends happily, whereas in no. 41 Robin does not return, and the narrator tries to comfort Marion. In the third group, nos. 42 and 43 , the narrator rejoices because he has found and wants to serve his perfect love. The fourth group, nos. 44 and 45, features unrequited love again. In no. 44 the narrator once again offers his love to the lady, but she refuses him. The story ends with an expression of negative feelings. The narrator laments the loss of Marion in no. 45, and, finally, the angry narrator comments in no. 46 , the "stinger," that the state of the world gets worse everyday and no one can be trusted.

In light of these summaries, a storyline does emerge. The narrator is looking for love in the first group and the beginning of the second group. Assuming he won the lady in no. 42 , in the third group he is rejoicing about his new love. In no. 44 his love leaves him, and he laments this loss in no. 45 . In no. 46 the narrator comments mainly on the clergy and l'estat $d u$ monde (the state of the world). If we read "between the lines" of this text it is not difficult to infer that the narrator has difficulty expressing anger toward his beloved and is substituting the brothers for her; thus, this displacement of his anger from women to the clergy is an appropriate ending to the story. While one has to infer a few key events (the winning and losing of the girl) the outline of a story is clearly present in the placement of triplum texts in the fascicle.

The motetus texts of Fascicle III, like those of the tripla, are characteristic of the Latin texts collected in the codex. According to Joel Relihan, the majority of Latin texts collected in the Montpellier Codex are "hymns to Mary." almost all of the Latin texts are sacred, there are a few non-sacred texts found in the

\footnotetext{
${ }^{76}$ Joel C. Relihan, "The Latin Texts," in The Montpellier Codex, vol. 4, ed. Hans Tischler (Madison: A-R Editions, 1985), xx.
} 
book, including a text about adultery, a set of complaints against hypocritical clergy, and a text lamenting the "sad state of Love in the modern world." In Fascicle III there are three non-Marian motetus texts, a complaint against hypocritical brothers, a set of epithets to the Cross, and a paraphrase of a Bible passage.

Marian epithets are common in thirteenth-century Latin texts, reflecting the veneration of the Virgin Mary. To the minds of the Middle Ages, the mystery of the virgin birth raised Mary to a level above all other mortal women. According to Penny Schine Gold, in her book The Lady and the Virgin, many saw Mary as a conduit to God, praying to her to plead with her Son for them, while others set Mary as the example for women, emulating her in an effort to get into Heaven. ${ }^{78}$ The motetus texts found in Fascicle III are characteristic of these Marian themes. In general, they consist solely of long lists of praises, or epithets, to the Virgin, some more poetic than others.

Within the eight motetus texts consisting of epithets to Mary, a myriad of images are connected to her. In addition to the expected praise of Mary's virginity and her Son who came to save sinners, common images pay tribute to Mary in these texts. These include references to light, Biblical figures, flowers, and petitions for Mary's intercession.

Four motetus texts use phrases containing the words lux (light) or fulget (shines) or irradia (shine) to describe the Virgin: nos. $36,38,43$, and 45 . Two, nos. 43 and 45 , use the phrase lumen luminum (light of lights) to describe Mary. In no. 36, the poet says that Mary fulget (shines) and in no. 38 Mary is described as the lux fidelium (light of the faithful). Biblical figures are used in three motetus texts, no. 36, 39, and 40. In no. 36

\footnotetext{
${ }^{77}$ Ibid. $1985), 68$.

${ }^{78}$ Penny Schine Gold, The Lady and the Virgin, (Chicago: The University of Chicago Press,
} 
Mary is likened to Noah's ark and Jacob's ladder. No. 39 recounts the story of Simeon holding the baby Jesus and thanking God. Like no. 36, no. 40 refers to Mary as the rod of Jesse.

The motetus texts frequently use flower imagery to describe the Virgin, similar to the use of flower imagery to elevate the poet-composer's lady in the triplum texts.

References to flowers are found in five of the eight Marian texts, nos. 38, 39, 40, 43, and 44, as seen in Table 4.3 .

Table 4.3. References to Flowers in Motetti of Fascicle III

\begin{tabular}{|l|l|}
\hline Motet No. & Flower Reference \\
\hline $\mathbf{3 8}$ & "rose without thorn" \\
\hline $\mathbf{3 9}$ & "The fragrant rose, the lily of the valleys" \\
\hline $\mathbf{4 0}$ & "princess of roses" \\
\hline $\mathbf{4 3}$ & "O flower of the valleys, O lily" \\
\hline $\mathbf{4 4}$ & $\begin{array}{l}\text { "The flower is plucked from the thorn, } \\
\text { the flower without the thorn withers, but } \\
\text { does not die. In love, the flower } \\
\text { embraces the flower of life; in this solace } \\
\text { it so refreshes itself in its own strength } \\
\text { that it does not suffer." }\end{array}$ \\
\hline
\end{tabular}

These references are all describing Mary; therefore, they are like the second group of flower references found in the tripla, those describing the narrator's love. As with all the epithets in this fascicle, the use of flower imagery to describe the Virgin Mary is another way for the medieval poet to elevate his subject above the typical woman. No. 44 , an Assumption text, is slightly different. Here, Mary is the flower plucked from the thorn of the earthly realm and assumed into Heaven. The tenor of this motet is taken from the Mass for the Feast of the Assumption, a direct relationship conceived by the poetcomposer. 
Petitions for Mary's intercession form a final common theme found in motetus texts. In the Middle Ages Mary was seen as a mediator between the people and God, so pleas for Mary's intercession on behalf of the people were common. Six of the eight Marian texts have some form of intercessory pleas in them; these include nos. 36, 38, 40, 43, 44, and 45 and are listed in Table 4.4.

Table 4.4. Intercessory Pleas found in Fascicle III

\begin{tabular}{|l|l|}
\hline Motet No. & Intercessory Plea \\
\hline $\mathbf{3 6}$ & "that she plead constantly with her Son to be kind" \\
\hline $\mathbf{3 8}$ & "the salvation for the sinner" \\
\hline $\mathbf{4 0}$ & "through you the dross of decay be cleansed away" \\
\hline $\mathbf{4 3}$ & "pardon of sinners" \\
\hline $\mathbf{4 4}$ & "the star of the sea impregnates the ear of her pious Son with her prayers" \\
\hline $\mathbf{4 5}$ & "through you may pardon be granted" \\
\hline
\end{tabular}

Some of these are direct pleas to Mary, as in nos. $36,40,44$, and 45 . In the remaining two, nos. 38 and 43, her status as intercessor is alluded to within the context of epithets. ${ }^{79}$ Returning to the three non-Marian motetus texts, we find no. 37 to be a complaint against the brothers. The poet censures their hypocrisy with the words Vestiti sunt enim dupplicibus, pace foris et intus fraudibus (For they are clothed duplicitously, in peace without and in deceit within). To protect oneself against them, the poet advises $t i b i$ Ioseph habeas (take Joseph as an example). The poet concludes by warning that Nullum esse gravius periculum quam in falsis fratribus per seculum (There is no graver danger in this world than in false brothers). This text stands out among the other motetus texts in this fascicle in multiple ways: 1) it is the only text that is not related to the liturgy of the

${ }^{79}$ There are many other types of epithets to Mary present in the motetus texts of Fascicle III; however, a comprehensive list is not possible within this general survey. 
church, and 2) it is the only text warning against something. According to Relihan, this type of text is rare among all the Latin texts of the Codex. ${ }^{80}$

The remaining two motetus texts are heavily based on the liturgy. No. 41 presents a text of epithets to the Cross. Resembling the Marian epithets found throughout the fascicle, this text praises the Cross as the Lux plenarie nubem luens tristicie (Light that totally dispels the cloud of sadness) and concludes by stating Crucem oportet si vis [lucis] vere gaudia sustinere (You must bear the Cross, if you desire the joys of the true light). According to Relihan, this text is unique among the Latin texts of the codex. ${ }^{81}$ Motet no. 42 presents another non-Marian text. This motetus' text paraphrases John 14:15-31, a message from Jesus that those that follow him will not be abandoned. The beginning of the passage is a reassurance of joy and reward: Conferam me secutis post lacrimas gaudium, premium post laboris tedium (I shall grant those that follow me joy after their tears, reward after the drudgery of their toil). The second part of the text presents instructions to the disciples: Inclitus Paraclitus divinitus tuum cor docebit. Et radicitus tuus spiritus Domino sic herebit, tutus ut introitus tutus sit et exitus (The glorious Paraclete will instruct your hearts from on high. And your spirit will cling so completely to the Lord that your coming in and your going out will be secure). Relihan states that this unique motetus is "remarkable for both its form and the beauty of its text." ${ }^{82}$ The three non-Marian motetti play an important role among the Latin texts; they bring variety to the fascicle.

${ }^{80}$ Relihan, $\mathrm{xx}$, states that, "the Latin texts [of Mo] are mostly prayers" and includes the "complaint against the hypocritical clergy" in the motetus of no. 57 (Fascicle IV) among his list of exceptions. The motetus text of no. 57 contains searing criticism against the clergy, written by Guillaume d'Auvergne. Possibly, Relihan did not count the Latin text of no. 37 as a "complaint against the hypocritical clergy" because the text only says "brothers" and not "clergy."

${ }^{81}$ Relihan, $x x$.
${ }^{82}$ Ibid. 
On the surface, these motets seem bifurcated, with tripla based in the court and motteti based in the church. The texts of each motet, however, are carefully selected and/or composed to fit with each other. In general, the nine motets that present both a courtly love text and a liturgically based text (nos. 36 and 38-45) are linked in their expression of different types of love, sacred and erotic. The texts of nos. 37 and 46 are linked in more subtle ways and will be discussed below.

Two techniques frequently used to link texts occur in no. 36. One is the presentation of similar words in both the motetus and triplum. Since the two texts are in different languages, this link depends on the listener's knowledge of both languages. ${ }^{83}$ Despite the different languages, both texts use words meaning joy and rejoice. In the triplum, the poet-composer uses the Old French words resbaudis (joy), renvoise (rejoices), and jolis (gay). The motetus line presents four forms of the word gaudere, translated as joy or rejoice. This language also relates to the tenor part, whose tag, et gaudbit, translates as "and will rejoice." The second means of tying the texts together in this motet is the use of similar phrases. In no. 36 , in the last line of the triplum the lady says, Aimi, ja ne m'en partirai, car loial ai l'ami (Alas, I have a loyal sweetheart and never will I part from him). In the motetus line, the poet, while praising Mary, says que tuos numquam mori deseris (you who never abandon your people to die). The vow of devotion apparent in these two texts unifies the two upper voices of the motet. Even though the two texts express the promise of loyalty to two different types of love, each expresses a similar sentiment; the maiden in the triplum is promising never to abandon

${ }^{83}$ This is another reason that it is assumed that these pieces were for the educated community. 
her lover, and in the motetus the narrator is praising Mary's devotion never to leave her people to die. And both of these promises are reasons to rejoice.

Another way in which the poet-composer unifies the texts of different voices is by using opposite or contrasting sentiments. This is most apparent in the two motets that use atypical texts: no. 37 which contains the complaint against hypocritical clergy in the motetus, and no. 46 which features the one sirventes triplum text, the lament about the state of the world. In no. 37 , the narrator of the triplum text grieves because his lady left him, while the poet of the motetus complains concerning hypocritical clergy. These two texts can be viewed as expressions of two differing views on love, one bitter, and one bittersweet. The poet in the triplum has lost his love, but still cares for her deeply, whereas the poet in the motetus is a scorned and bitter parishoner, upset with the clergy. A similar reading is possible in no. 46 ; however, the voices are reversed. In the triplum, the poet is the bitter party, angry with people for being hypocritical and full of jealousy and pride. The motetus text praises the womb of Mary for giving birth to the One who mundi nephas abstersit impium (washed away the foul evil of the world). This text refers to both the cause and the solution to the triplum's text.

It is notable that each set of upper-voice texts contains one text lamenting the state of the world: the motetus of no. 37 and the triplum of no. 46 . These two texts create a different link between the two voices, one that also holds together the beginning and end of the eleven motets, creating an ironic frame for the fascicle. Since both texts mention that people, especially clergy, are hypocritical and full of envy, this frame alters the audience's understanding of all intervening texts. This frame sets up an understanding of the hypocritical clergy as "bad" and allows romantic love to be seen as "good." 
Another aspect of the motetus texts that must be taken into account is their relation to their tenor texts. Six of the eleven motets use the tenor identifying word or words in the motetus text. The motets that use this technique of unifying the tenor and motetus are nos. $36,37,41,42,44$, and 46 . In nos. $37,41,42$, and 44 the word from the tenor tag occurs as the last word of the motetus text. In no. 36, the tenor tag is et gaudebit. Gaudebo is the antepenultimate word in the motetus text, and other forms of gaudebit are used previously in the text for a total of four times. No. 46 incorporates its entire tenor source text in the motetus.

Tenor source text: Beata viscera Marie virginis que portaverunt eterni patris filium. Blessed is the womb of Mary the Virgin which bore the Son of the Eternal Father.

Motetus text: $\quad$ Beata viscera Marie virginis tam salutifera tantique nominis, que portaverunt proprium eterni patris filium, qui sumendo carnis exilium mundi nephas abstersit impium, nobis p[a]rando premium, iter ad gaudium.

Blessed is the womb of Mary the Virgin, so salvific and of so great a name, which bore the very Son of the Eternal Father: in submitting to the exile of the flesh, He washed away the foul evil of the world, by giving us reward, a path to joy.

True to the genesis of the motet genre, the motetus text takes the tenor source text and expounds upon it by adding epithets.

The use of different languages in the texts of Fascicle III adds depth to the polytextual motet genre and creates a fascinating tapestry of words. The medieval audience had to sort out two texts, in different languages, dealing with different types of love, sacred and erotic; this was the challenge in the genre. 


\section{CHAPTER 5: CONCLUSIONS: THE UNITY OF FASCICLE III}

The unity of Fascicle III is based upon the weaving together of seemingly

disparate elements: the liturgically based tenors and their structural pattern of alternating rhythmic modes, and the contrasting motetus and triplum texts. The ways in which the different voices work together, with the different languages contrasting elements from sacred and secular genres, is quite ingenious, suggesting that the medieval poet-composer experimented at length with the texts of these motets, carefully combining languages and seemingly unrelated imagery. Links between voices, primarily textual links and those relating to the rhythmic modes, contribute to the unity of the fascicle, specifically links between the tenor and motetus texts, the tenor and triplum texts, and finally between the motetus and triplum texts. These links vary from similar references to common textual themes.

The tenor and motetus lines often include related texts meant to appear together, as suggested by the fact that ten of the eleven bilingual motets preserved in Fascicle III are preserved as single or double Latin motets. Some of these relationships are direct, as in nos. 41,44 , and 46 . No. 41 presents a text of epithets to the Cross, and its tenor, Sustinere (Sustains), is from a chant from the Feast of the Finding of the Holy Cross. No. 44 is based on an Assumption tenor, while its motetus text, Flos de spina, relates the Assumption of Mary to the flower plucked from the thorn. The final motet, no. 46, uses the entire tenor text in its motetus. No. 43 is the only motet not preserved as a single Latin motet. 
In less direct relationships, six of the motets employ the tenor tag in the motetus text. This link occurs in nos. $36,37,41,42,44$ and 46 . Usually, the tag word appears once in the motetus text, typically, near the end of the text. In the cases of nos. 36,37 , 41,42 , and 44 , the tenor tag is found in the last line, usually as the last word of the text. As mentioned in Chapter 4, no. 36 uses its tenor tag a total of four times, three times in the last line.

In general, liturgical connotations unify the tenor and motetus voices: the tenors are from the plainchant repertoire and the motetus texts feature veneration of the Virgin Mary, the Cross as in no. 41 , presentation of Biblical texts as in no. 42 , or critical commentary on hypocritical brothers as in no. 37 . These two lines of the bilingual motets serve as a reminder of the origins of the genre; the motet began as a liturgical genre where a new text was added to existing clausula, and the newly added text usually commented upon the tenor source on which it was built.

Relationships between tripla and tenors are more difficult to find. The most direct correspondence is the time of year depicted in the triplum texts and the time of the liturgical year the tenor sources were sung. In the eight triplum texts that either mention or imply a time of year -- nos. $36,37,40,41,42,43,44$, and 45 -- the references are all to spring or summer. The tenor sources, as mentioned in Chapter 2, all fall between 24 February and 15 August, a span which encompasses spring and summer. While these seasons are typically celebrated in courtly love texts, the fact that all the tenor sources fall within this period shows some degree of planning on the part of the compiler.

In one motet, no. 46 (the "stinger" in which the triplum's narrator rails against the brothers), a striking relationship between the triplum and tenor becomes clear upon close 
inspection. The poet-composer has set his critical, sirventes triplum text above a tenor taken from a communion antiphon, sung in the Mass at the point of the sharing of the elements of communion among the faithful. The irony of this combination intensifies the triplum's complaint against hypocritical clergy. Furthermore, the text of the tenor source, Beata viscera Mariae Virginis quae portaverunt aeterni Patris Filium (Blessed womb of the virgin, which carried the Son of the eternal Father), stresses the generosity of the Father's gift to the world as well as Mary's self-giving role in the incarnation. The motetus text also figures into this relationship by presenting the entire text of the tenor source and elaborating upon it, further highlighting the irony of the triplum's denouncement of the clergy.

Another interesting relationship can be found in the crux motet, no. 41. This motet's tenor is Sustinere (Sustain), and in the triplum Marion is sad because Robin is gone. The narrator attempts to console her. If this text is read on another level, substituting Biblical characters for the earthly ones, this text relates to the essence of the tenor's source feast. In this alternate reading, if Marion stands for Mary and Robin symbolizes Christ, Mary is grieving the loss of Christ on the Cross. It is difficult to ascertain who the narrator represents in his attempt to console Mary. The narrator might represent the Cross, relating to the tenor tag Sustinere. A second possibility is that the narrator stands for John if one thinks of Jesus's statement that Mary was now John's mother and he should take care of her. ${ }^{84}$ No matter who took on the role of the narrator, the fact that this triplum text was paired with this tenor and motetus, shows a great deal of

\footnotetext{
${ }^{84}$ John 19:27.
} 
planning. This triplum text, not a typical courtly love text, was carefully chosen or written to fit with this tenor and motetus.

A final motet significant for the relationship between its tenor and triplum is no. 37, the motet whose motetus presents commentary against the brothers. This motet's tenor is taken from the Gradual for Easter Week. The tenor tag, In seculum, means "without end" in the chant. The triplum text expresses negative emotions about love; the narrator is upset because his lady has left him. Despite her leaving, he vows to be true to her always. Relationships between this triplum and tenor appear on two levels. First, the narrator is upset, saying, Mout me fu gries li departir de m'amiete, la bele au cors gent (The departure of my little sweetheart, the fair beauty, was so painful for me!) This relates to the time of year in the tenor source chant, Easter, a time when the church is lamenting the loss of Christ on the Cross and his subsequent resurrection. ${ }^{85}$ Both lines are lamenting the loss of someone. Secondly, the tenor tag, "without end," is echoed in the narrator's promise to his departed lover:

Car je voz empri, faites de moi vostre loial ami: Por vous mourrai, se n'avez pitié de m[o]1! Ostés moi de la prison, don't garrison avoir ne porrai, se de vous aucun secors $n$ 'ai. Je vous servirai tot les jours que je vivrai et ja nul jor ne m'en departirai.

I beseech you, make me your loyal sweetheart: I will die on account of you if you have not pity on me! Take me out of the prison from which I can never be released without help from you. I will serve you as long as I shall live and never leave off serving you.

The narrator promises to serve his lover always, even though she has left him. When read in the context of the church, this is a promise from the people to Christ to always follow him, even though $\mathrm{He}$ has left the earthly realm. When read with the motetus text, the commentary on the hypocritical brothers, this motet takes on another dimension. The

${ }^{85}$ Even though Easter is a joyful time in the church, the Pascal season is still one of loss, the loss of the earthly Christ figure. 
tenor and triplum espouse the goodness of the church and love, whereas the motetus contradicts the other two texts, interjecting the fact that people cannot be trusted into the more idealistic tenor and triplum texts. While relationships between the triplum and tenor are not readily apparent in this motet, with a little deductive reading the logic behind the poet-composer's placement of texts in no. 37 becomes clear.

Relationships between the triplum and motetus texts are also less than obvious. In most cases, the elevation of the poet-composer's "lady" is the unifying theme. Most texts include lists of epithets praising Marion's beauty or the Virgin's grace. Although different in their language and the focus of their adoration, these texts are founded on the same underlying sentiment: love. For instance, the triplum and motetus of no. 43 both praise love. The triplum states that the narrator wants to serve the perfect love that he desires, while the motetus praises Mary. Both texts praise the object of the narrator's love, whether an earthly or a heavenly figure, with similar imagery. The narrator in the triplum praises his lady's vis cler (bright face) and cuer sans fauser (true heart). Likewise, the narrator in the motetus says that Mary is the verum lumen luminum (true light of lights) and plena gratia (full of grace). These similar statements, in different languages, create links between these seemingly disparate texts. Both voices also use flower imagery, but it is used differently in the two texts. The triplum uses references to flowers to set up the pastourelle scene, Quant voi l'erbe reverdir et le tans seri et cler et le rosier espanir et le rossignol chanter (When I see the grass turn green again, the weather clear and calm, the rose bushes blooming and the nightingale singing). In the motetus text, flower imagery is used to elevate Mary, Flos convallium, lilium, vera semper gaudia in eternal Gloria (O flower of the valleys, O lily, true joys forever in 
eternal glory). Despite the fact that this imagery is used for different purposes found in the two texts, it holds them together. One can find similar interrelationships in all of the motets in Fascicle III. These markedly different texts, in different languages, are not as bifurcated as they seem upon first glance.

Another link between the upper voice texts is the fact that each contains one text criticizing the state of the world: the motetus of no. 37 and the triplum of no. 46 . The motetus of no. 37, which says that no one should be trusted and most people are hypocrites, is directly echoed in the triplum of no. 46 , which states that the state of the world gets worse every day and that people are full of pride and envy. These two texts create a different link between the motteti and tripla of the fascicle, that is, one of critical feelings. It is also notable that these two motets hold together the beginning and end of the fascicle; no. 37 is second and no. 46 is the end of the original fascicle. This creates an ironic frame for the fascicle. Since both texts mention that people, especially clergy, are hypocritical and full of envy, this frame alters the audience's understanding of all intervening texts.

A common theme of abandonment unites the triplum and motetus texts of Fascicle III. In the tripla of nos. $39,40,41$, and 45 , two of the earthly characters $\cdots$ the narrator and Marion -- are portrayed, in some sense, as abandoned. In nos. 39 and 45, the narrator expresses sorrow at having been "abandoned" by his lady, and in nos. 40 and 41 Marion is sad because of Robin's departure. In the motetus texts the idea of abandonment is also present, especially in nos. 42 and 44 . The motetus of no. 42 paraphrases Christ's promise to his disciples that He will never abandon them, while the 
motetus of no. 44 contains the extended flower metaphor symbolizing Mary's Assumption to Heaven.

Some motetus texts are strategically placed with relation to triplum texts, especially those of nos. 44 and 45 . In the motetus of no. 44 Mary is assumed to heaven and in the triplum of no. 45 , the following motet, the narrator laments Marion's departure. If we once again substitute Biblical characters for the earthly ones, in this case Mary for Marion and the people of the world for Robin, the people can be seen as lamenting the loss of Mary after her assumption. After this set of motets, the "stinger" text of no. 46 is presented; L'estat du monde et la vie va empirant chascun jour car plein d'orgueil et d'envie sunt cil qui samblent meillor (Life and the state of the world get worse everyday, for those who seem the best are actually full of pride and envy). This can be seen as the later result of the loss of Jesus and Mary. Interplay between triplum and motetus texts creates even more links among the motets of the fascicle and within individual motets.

Finally, many aspects of this fascicle suggest that this is not a random grouping of motets, but a well-thought out placement of a careful selection of pieces, showing the poet-composer's skill at compilatio, the ordering individual items in a manuscript. Two aspects of these motets in particular, including the pattern of rhythmic modes and the storyline in the triplum, were not lost on the compiler.

The alternating pattern of rhythmic modes in the tenor voices seems to be one foundational ordering of the fascicle. ${ }^{86}$ The alternation of a mode 5 tenor with a differing one, is clearly not coincidental. No. 41 is a unique motet, located precisely in the middle

\footnotetext{
${ }^{86}$ See Chapter 2.
} 
of the fascicle, as the sixth of the eleven motets. This motet's Latin text begins with the words Crux forma penitentie (Cross, shape of penance) and continues with a list of epithets to the Cross, praising its worth. The tenor source for this motet, the Alleluia for the Feast of the Finding of the Holy Cross, is directly related to the motetus text. The most interesting feature of no. 45 is its placement at the mid-point of the fascicle, which, according to its text, coincides with the compiler's abandonment of the tenor rhythmic pattern for this one motet.

A secondary grouping of rhythmic modes can be seen in the triplum and motetus lines, based on their text declamation. ${ }^{87}$ The first half of the fascicle includes motets with a mode 6 triplum and alternating modes 1 and 2 in the motetus. At the midpoint, no. 41, text declamation in both voices is based in mode 3 (the perfect number in medieval times). Beginning with no. 41 , the upper voices present the same basic text declamation, either mode 1, 2, or 3 in each motet. The final motet, no. 46, again presents text declamation based in mode 3 for both voices. The placement of the mode 3 motets as the middle and final motets in the fascicle also implies a deliberate action on the part of the compiler.

In this study, a number of unifying characteristics of the motets of Fascicle III have been identified1. Musical characteristics which unify the motets include primarily the ordering of rhythmic modes in all three voices. Textual characteristics also work to unify the motets. These characteristics include the use of similar imagery in the tripla and motetti, the time of year referenced in the tenors and tripla, the use of courtly genres, and the storyline in the tripla. The motetti and tripla are unified in their overriding

\footnotetext{
${ }^{87}$ See Chapter 3, especially Table 3.3.
} 
adoration and elevation of a lady, whether it be an earthly figure (Marion) or the Virgin. Placement of specific motets holds the small group together, especially the location of the two critical texts at the beginning and end of the fascicle, the motetus of the second motet, no. 37 , and the triplum of the final motet, no. 46 . The placement of no. 41 is also notable; the motet praises the Cross in its motetus, the central voice of the central motet. This motetus is found in the exact middle of the fascicle. All these features of the eleven motets in Fascicle III work together to hold the group together. Even though there is no way of knowing exactly what the poet-composer and/or the compiler was thinking when grouping these motets together, it is clear that he did not just randomly select motets and put them together in this fascicle haphazardly. These motets are too carefully placed for their placement to be coincidental.

Fascicle III, the smallest fascicle of the Montpellier Codex, can function as a guide to the rest of the codex. In a larger study, one could look at the compilatio of the entire manuscript, following lines of inquiry presented here. Are all the fascicles organized by tenor rhythmic mode? Is there some pattern to the rhythmic modes present in the upper voices? Do the additions to the fascicles relate to the original contents of the fascicle, or were they placed there simply because there were extra folios? As mentioned in Chapter 1, many studies have already been conducted on the textual characteristics of the motets in the codex, but not as many have studied the musical characteristics. A myriad of aspects of Mo have not been studied in depth.

Fascicle III of the Montpellier Codex is a fascinating study in the juxtaposition of sacred and secular texts and in medieval compilatio. Elements of both text and music work to unify this smallest fascicle of Mo. Although the music of Fascicle III presents 
typical elements of the genre as a whole, the patterned use of alternating rhythmic modes shows that the compiler was aware of the musical aspects of the pieces as well as the textual aspects. The similarities between the elevation of subjects of the different languages, the well-placed texts that bring variety to the fascicle, the grouping of motets by rhythmic modes, and the interplay between sacred and erotic love create a unique collection of motets within the old corpus of the Montpellier Codex. 


\section{REFERENCES}

\section{Facsimiles and Transcriptions}

Anderson, Gordon A., ed. Compositions of the Bamberg Manuscript: Bamberg, Staatsbibliothek, Lit. 115. Rome: American Institute of Musicology, 1977.

Aubry, Pierre, ed. Cent motets du XIIIe siècle, publiés d'après le manuscrit Ed. IV. 6 de Bamberg. New York: Broude Brothers, 1964. (Reprint of the 1908 Paris edition.)

Baxter, J.H., ed. An Old St. Andrews Music Book (Cod. Helmst, 628). New York: American Musicological Society Press, 1973.

Dittmer, Luther, ed. Facsimile of the Manuscript Firenze, Biblioteca mediceolaurenziana, Pluteo 29, I. Ottawa: Institute of Mediaeval Music, 1966. , ed. Faksimile-Ausgabe der Handschrift Wolfenbüttel 1099. Ottawa: Institute of Mediaeval Music, 1969.

Gennrich, Friedrich, ed. Faksimile-Ausgabe der Hs La Clayette. Darmstadt: N. p., 1958.

Roesner, Edward H., ed. Le Magnus Liber Organi de Notre-Dame de Paris. Vol. V, Les clausules a deux voix du manuscrit de Florence, Biblioteca medicea-laurenziana, Pluteus 29.1, Fascicule $V$, transcribed by Rebecca Baltzer. Les Remparts, Monaco: Editions de L'Oiseau-Lyre, 1995.

Rokseth, Yvonne, ed. Polyphonies du XIIIe siècle: le manuscript H 196 de la Faculté de Médecine de Montpellier. 4 vols. Paris: Editions de l'Oiseau lyre, 1935.

Tischler, Hans, ed. The Montpellier Codex. 4 vols. Madison: A-R Editions, 1985.

\section{Indexes}

Ludwig, Friedrich. Repertorium organum recentoris et motetorum vetustissimi stili. Vol. 1, pt. 1: Halle, 1910; reprint edited by Luther A. Dittmer, Musicological Studies, no. 7 (Brooklyn and Hildesheim: Institute of Mediaeval Music, 1964); vol. 1 pt. 2 edited by Luther A. Dittmer, Musicological Studies, no. 26 (Brooklyn: Institute of Mediaeval Music, 1978); Vol. 2 edited by Luther A. Dittmer, Musicological Studies, no. 17 (Brooklyn: Institute of Mediaeval Music, 1972). 
van der Werf, Hendrik. Integrated Directory of Organa, Clausulae, and Motets of the Thirteenth Century. Rochester, New York: by the author, 1989.

\section{Secondary Studies}

Anderson, Gordon A. "Notre Dame Bilingual Motets: A Study in the History of Music c. 1215-1245." Miscellanea Musicologica 3 (1968): 50-145.

. "A Small Collection of Notre Dame Motets ca. 1215-1235." Journal of the American Musicological Society 22, no. 2 (Summer 1969): 157-96.

Baltzer, Rebecca A. "The Polyphonic Progeny of an Et gaudebit: Assessing Family Relations in the Thirteenth-Century Motet." In Hearing the Motet: Essays on the Motet of the Middle Ages and Renaissance, ed. Dolores Pesce, 17-27. New York: Oxford University Press, 1997.

Bishop, Morris. The Middle Ages. New York: Houghton Mifflin Company, 1996.

Crocker, Richard. "French Polyphony of the Thirteenth Century." In The New Oxford History of Music, vol. 2: The Early Middle Ages to 1300, ed. Richard Crocker and David Hiley, 636-678. New York: Oxford University Press, 1990.

Dittmer, Luther. "The Ligatures of the Montpellier Manuscript." Musica Disciplina 9 (1955): 35-55.

Evans, Beverly Jean. "The Unity of Text and Music in the Late Thirteenth-Century French Motet: A Study of Selected Works from the Montpellier Manuscript, fascicle VII." Ph.D. diss., University of Pennsylvania, 1983.

Everist, Mark. French Motets in the Thirteenth Century: Music, Poetry, Genre. New York: Cambridge University Press, 1994.

Gold, Penny Schine. The Lady and the Virgin. Chicago: The University of Chicago Press, 1985.

Harbinson, Denis. "Consonance and Dissonance in the Old Corpus of the Montpellier Manuscript." Musica Disciplina 22 (1968): 5-13.

. "The Problem of Rests in Pre-Franconian Notation." Soundings 1, no. 1 (Fall 1970): 24-9.

Hart, Josephine Spencer. "Musical Structure in the Thirteenth-Century Motet: An Analytical Study of the Motets in the Old Corpus of the Montpellier Manuscript." D.M.A. diss., University of Oregon, 1977. 
Hoekstra, Gerald R. "The French Motet as Trope: Multiple Levels of Meaning in Quant florist la violete/El mois de mai/Et gaudebit." Speculum 73, no. 1 (January 1998): $32-57$.

Huot, Sylvia. Allegorical Play in the Old French Motet: The Sacred and the Profane in Thirteenth-Century Polyphony. Stanford: Stanford University Press, 1997.

- "Polyphonic Poetry: The Old French Motet and Its Literary Content." French Forum 14 (September 1989): 261-78.

. "Textual Interplay: Sacred and Erotic Love in Motets of the Montpellier Codex." Revista de Musicología 16, no. 3 (1993): 4-9.

Kendrick, Laura. The Game of Love: Troubadour Wordplay. Berkeley and Los Angeles: University of California Press, 1988.

Kidwell, Susan A. "The Integration of Music and Text in the Early Latin Motet." Ph.D. diss., The University of Texas at Austin, 1993.

- "The Selection of Clausula Sources for Thirteenth-Century Motets: Some Practical Considerations and Aesthetic Implications." Current Musicology 64 (1998): 73-103.

Mathiassen, Finn. The Style of the Early Motet: An Investigation of the Old Corpus of the Montpellier Manuscript. Copenhagen: Dan Fog Musikforlag, 1966.

Nathan, Hans. "The Function of Text in French Thirteenth-Century Motets." The Musical Quarterly 28, no. 4 (October 1942): 445-462.

Page, Christopher. "The Performance of Ars Antiqua Motets." Early Music 16, no. 2 (May 1988): 147-164.

Parsoneault, Catherine Jean. "The Montpellier Codex: Royal Influence and Musical Taste in Late Thirteenth-Century Paris." Ph.D. diss., The University of Texas at Austin, 2001.

Pesce, Dolores. "The Significance of Text in Thirteenth-Century Latin Motets." Acta Musicologica 58, no.1 (January-June 1986): 91-117.

. "A Revised View of the Thirteenth-Century Latin Double Motet." Journal of the American Musicological Society 40, no. 3 (Fall 1987): 405-442.

Reaney, Gilbert, ed. Manuscripts of Polyphonic Music: Eleventh - Early Fourteenth Century. Vol. B IV part 1, Repertoire International des Sources Musicales. Munich-Duisburg: G. Henle, 1964. 
Robertson, Anne Walters. The Service Books of the Royal Abbey of Saint-Denis.

Oxford: Clarendon Press, 1991.

Sanders, Ernest H. French and English Polyphony of the Thirteenth and Fourteenth Centuries: Style and Notation. Brookfield, Vermont: Ashgate Publishing Company, 1988.

and Peter M. Lefferts. "Sources, MS." In The New Grove Dictionary of Music and Musicians, $2^{\text {nd }}$ ed. Edited by Stanley Sadie and John Tyrrell, 23: 791-930. New York: Grove Dictionaries, 2001.

Smith, Norman E. "From Clausula to Motet: Material for Further Studies in the Origin and Early History of the Motet." Musica Disciplina 34 (1980): 29-65.

. "An Early Thirteenth-Century Motet." In Models of Musical Analysis: Music before 1600, ed. Mark Everist, 20-40. Cambridge: Blackwell Publishers, 1992.

Smith, Robyn Elizabeth. French Double and Triple Motets in the Montpellier Manuscript: Textual Edition, Translation and Commentary. Ottawa: Institute of Mediaeval Music, 1997.

Spottswood, Louisa. "The Influence of Old French on Latin Text-Setting in Early Measured Polyphony." In Beyond the Moon: Festschrift Luther Dittmer, ed. Bryan Gillingham and Paul Merkley, 163-82. Ottawa: The Institute of Mediaeval Music, 1990.

Tischler, Hans. The Style and Evolution of the Earliest Motets (to circa 1270). Ottawa: Institute of Mediaeval Music, 1985.

Wolinski, Mary Elizabeth. "The Montpellier Codex: Its Compilation, Notation, and Implications for the Chronology of the Thirteenth-Century Motet." Ph.D. diss., Brandeis University, 1988. 


\section{CURRICULUM VITAE}

NAME: Kimberly Adelle Harris

ADDRESS: 1225 S. First St. Apt. 3

Louisville, KY 40203

DOB: $\quad$ Town and Country, Missouri - 11 November 1978

EDUCATION: B.A. Music (General Concentration with Cello Emphasis)

Truman State University, Kirksville, Missouri

1997-2001

M.M. Music History

University of Louisville, Louisville, Kentucky

2001-2003

HONORS: Pi Kappa Lambda (April 2000) 